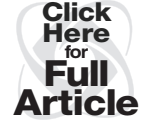

\title{
Variable crustal structure along the Juan de Fuca Ridge: Influence of on-axis hot spots and absolute plate motions
}

\author{
Suzanne M. Carbotte \\ Lamont-Doherty Earth Observatory, Earth Institute at Columbia University, Palisades, New York 10964, USA \\ (carbotte@ldeo.columbia.edu) \\ Mladen R. Nedimović \\ Lamont-Doherty Earth Observatory, Earth Institute at Columbia University, Palisades, New York 10964, USA
}

Department of Earth Sciences, Dalhousie University, Halifax, Nova Scotia B3H 4J1, Canada

Juan Pablo Canales

Woods Hole Oceanographic Institution, Woods Hole, Massachusetts 02543, USA

Graham M. Kent and Alistair J. Harding

Scripps Institution of Oceanograpy, University of California, San Diego, La Jolla, California 92093, USA

\section{Milena Marjanović \\ Lamont-Doherty Earth Observatory, Earth Institute at Columbia University, Palisades, Nerw York 10964, USA}

[1] Multichannel seismic and bathymetric data from the Juan de Fuca Ridge (JDFR) provide constraints on axial and ridge flank structure for the past 4-8 Ma within three spreading corridors crossing Cleft, Northern Symmetric, and Endeavour segments. Along-axis data reveal south-to-north gradients in seafloor relief and presence and depth of the crustal magma lens, which indicate a warmer axial regime to the south, both on a regional scale and within individual segments. For young crust, cross-axis lines reveal differences between segments in Moho two-way traveltimes of 200-300 ms which indicate $0.5-1 \mathrm{~km}$ thicker crust at Endeavour and Cleft compared to Northern Symmetric. Moho traveltime anomalies extend beyond the $5-15 \mathrm{~km}$ wide axial high and coincide with distinct plateaus, 32 and $40 \mathrm{~km}$ wide and 200-400 m high, found at both segments. On older crust, Moho traveltimes are similar for all three segments $(\sim 2100 \pm 100 \mathrm{~ms})$, indicating little difference in average crustal production prior to $\sim 0.6$ and $0.7 \mathrm{Ma}$. The presence of broad axis-centered bathymetric plateau with thickened crust at Cleft and Endeavour segments is attributed to recent initiation of ridge axiscentered melt anomalies associated with the Cobb hot spot and the Heckle melt anomaly. Increased melt supply at Cleft segment upon initiation of Axial Volcano and southward propagation of Endeavour segment during the Brunhes point to rapid southward directed along-axis channeling of melt anomalies linked to these hot spots. Preferential southward flow of the Cobb and Heckle melt anomalies and the regional-scale south-to-north gradients in ridge structure along the JDFR may reflect influence of the northwesterly absolute motion of the ridge axis on subaxial melt distribution. 
Components: 12,634 words, 16 figures, 2 tables.

Keywords: mid-ocean ridges; Juan de Fuca Ridge; hot spot; multichannel seismic.

Index Terms: 7245 Seismology: Mid-ocean ridges; 7219 Seismology: Seismic monitoring and test-ban treaty verification; 8137 Tectonophysics: Hotspots, large igneous provinces, and flood basalt volcanism.

Received 3 December 2007; Revised 18 April 2008; Accepted 19 May 2008; Published 2 August 2008.

Carbotte, S. M., M. R. Nedimović, J. P. Canales, G. M. Kent, A. J. Harding, and M. Marjanović (2008), Variable crustal structure along the Juan de Fuca Ridge: Influence of on-axis hot spots and absolute plate motions, Geochem. Geophys. Geosyst., 9, Q08001, doi:10.1029/2007GC001922.

\section{Introduction}

[2] The largest-scale variations in the structure of the world's mid-ocean ridges (MORs) arise from the influence of plate motions and mantle hot spots on mantle upwelling and melt delivery beneath the spreading axis. First-order changes in ridge structure are observed as a function of spreading rate, which reflect the influence of rate of plate separation on mantle upwelling, melt extraction, and crustal formation [e.g., Macdonald, 1982; Small, 1998]. The intersection of MORs with mantle hot spots gives rise to large variations in ridge structure at constant spreading rate that can be comparable to changes observed across the spreading rate spectrum [e.g., Iceland, Galapagos, see Ito et al., 2003 and references therein]. However, significant variations in ridge properties are also observed distant from prominent hot spots and along MORs at all spreading rates which are linked to the tectonic segmentation of ridges defined by discontinuities at a range of scales [e.g., Langmuir et al., 1986; Macdonald et al., 1988; Lin et al., 1990]. The origins of this segmentation are not well understood and effects of both plate kinematics and small-scale compositional or thermal heterogeneities in the mantle have been considered [e.g., Schouten et al., 1985; Langmuir et al., 1986; Lonsdale, 1989; Lin and Phipps Morgan, 1992]. Studies of spatial and temporal variations in ridge structure within constant spreading sections of the MOR are needed to understand the contributions of plate kinematics and mantle processes to ridge segmentation. The Juan de Fuca Ridge (JDFR) in the Northeast Pacific is a near constant rate intermediate spreading ridge with variable ridge structure and a history of near ridge and on-axis hot spot volcanism. With northwesterly absolute motion of the JDFR axis, the ridge has recently intersected the Cobb mantle anomaly leading to the formation of an on-axis hotpot at Axial Volcano [Karsten and
Delaney, 1989; Desonie and Duncan, 1990]. The ridge axis is segmented into a series of discrete spreading segments, each with distinct structure and recent tectonic history. From south to north, the seven segments are Cleft, Vance, Axial, Coaxial, Northern Symmetric or Cobb, Endeavour and Middle/West Valley segments (Figure 1).

[3] In 2002, we conducted an extensive multichannel seismic reflection survey of the JDFR axis and flanks during R/V Maurice Ewing expedition EW0207 (Figure 1). Data were collected within the near axis region [Canales et al., 2005, 2006; Carbotte et al., 2006; Van Ark et al., 2007] as well as along three, ridge flank transects crossing the Cleft, Northern Symmetric and Endeavour segments and extending to crustal ages of 4-8 Ma [Nedimović et al., 2005b]. The primary motivation for the flank study was to investigate upper crustal structure and the role of sediment burial, basement age, and basement relief on crustal alteration due to ridge flank hydrothermal circulation (M. Nedimović et al., Upper crustal evolution along the Juan de Fuca Ridge flanks, submitted to Geochemistry, Geophysics, Geosystems, 2008). The Mohorovicic discontinuity (Moho) was also well imaged along these transects providing constraints on structure of the whole crust within the region. Initial results reported by Nedimovic et al. [2005b] focus on the discovery of sub-Moho reflection events found both near the ridge axis $(<20 \mathrm{~km})$ as well as near off-axis propagator wakes, which may correspond to magma sills emplaced in the Moho transition zone (MTZ).

[4] In this study, bathymetric and seismic data from Cleft, Northern Symmetric and Endeavour segments are used to characterize crustal structure at these distinct spreading segments. Along-axis seismic data provide constraints on the current distribution of magma in the crust, while the cross-axis flank transects provide constraints on 


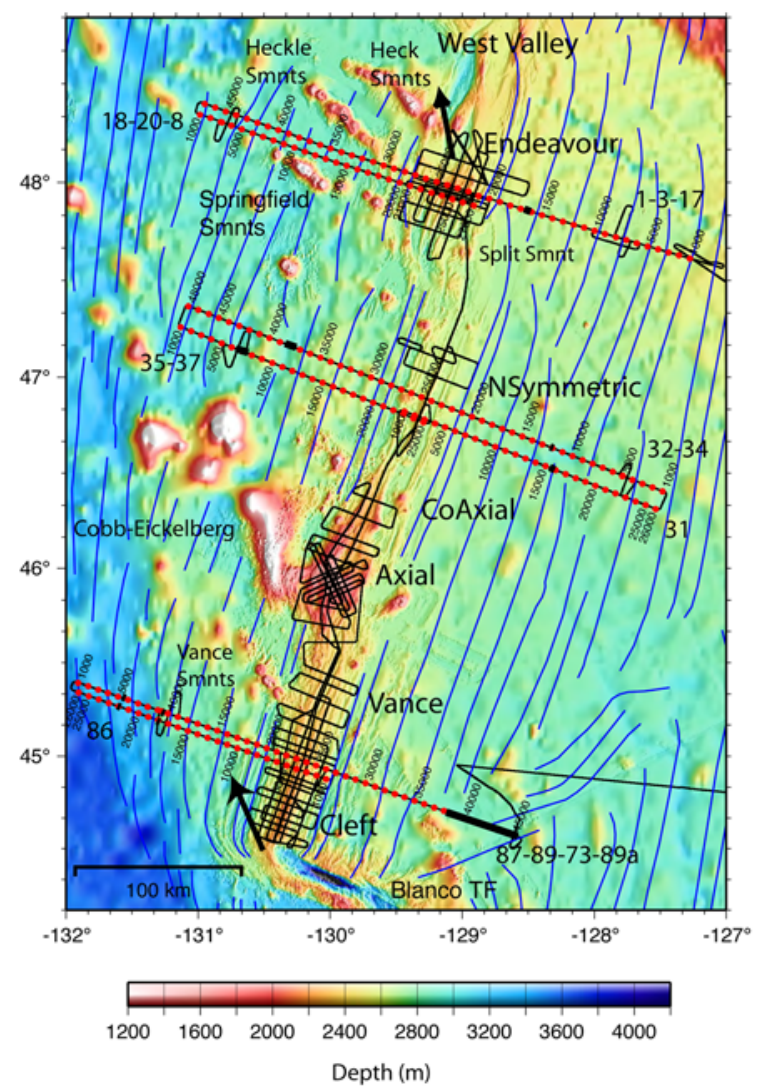

Figure 1. Track lines of the 2002 multichannel seismic survey (black lines) superimposed on regional bathymetry of the Juan de Fuca Ridge (JDFR). Ridge flank seismic transects are labeled with line numbers and common midpoint (CMP) locations (red dots mark every $1000 \mathrm{CMP}$ ). JDF ridge segments and prominent seamount chains are labeled. Blue lines show locations of magnetic isochrons from Wilson [1993]. Thick black lines along seismic transects show extent of propagator pseudofaults highlighted with gray shading in Figures $4 a-4 c$. Black arrows show the absolute motion of the ridge axis calculated from the HS3-Nuvella plate motion model [Gripp and Gordon, 2002]. Ridge migration velocity varies from $-32^{\circ}, 32 \mathrm{~mm} / \mathrm{a}$ along the southern JDFR to $-21^{\circ}, 28 \mathrm{~mm} / \mathrm{a}$ along the northern JDFR.

the history of crustal production within each segment for the past 4-8 Ma. The combined data set indicates a recent history of enhanced crustal production at Cleft and Endeavour segments which we associate with initiation of nearby on-axis hot spots. Larger-scale regional gradients are observed along the length of the JDFR in seafloor and subseafloor structure that cannot be simply attributed to hot spot/melt anomaly proximity and may reflect influence of plate motions on melt distribution beneath the axis.

\section{Regional Setting and Recent Tectonic History}

[5] The JDFR is a $480-\mathrm{km}$-long intermediate-rate spreading center $(56 \mathrm{~mm} / \mathrm{a}$ [Wilson, 1993]) located within the northeast Pacific between the Blanco and Sovanco fracture zones (Figures 1, 2a, 2b, and $2 c)$. The ridge axis migrates to the northwest in the absolute motion reference frame, oblique to the spreading direction $\left(110^{\circ}\right)$, at $\sim 31 \mathrm{~mm} / \mathrm{a}$ [Small and Danyushevsky, 2003]. The seven spreading segments of the current ridge axis are each $\sim 50$ $100 \mathrm{~km}$ long, separated by nontransform offsets up to $30 \mathrm{~km}$ in length. All are second-order segments in the hierarchy of Macdonald et al. [1988]. Segment overlap ranges from $6 \mathrm{~km}$ at Cleft/Vance, to $>30 \mathrm{~km}$ at the Cobb offset between Endeavour and Northern Symmetric segments.

[6] A prominent feature of the JDF region is abundant seamount volcanism and interaction of this volcanism with seafloor spreading processes [Davis and Karsten, 1986; Hammond, 1997]. Seamounts are found primarily on the Pacific plate, both as isolated edifices and in chains, several of which lie close to and intersect the JDFR axis. The Cobb-Eickelberg seamount chain, formed by motion of the Pacific plate over the Cobb hot spot, is one of the most prominent chains in the region. Axial Volcano lies at the intersection of the CobbEickelberg seamounts with the JDFR and is believed to mark the current location of the Cobb hot spot (Figure 2b). Here, a shallow $(1450 \mathrm{~m})$ dome shaped central volcano with a $2 \mathrm{~km}$ wide breeched caldera is bounded by two major rift zones composed of elongate volcanic ridges and small volcanic cones [Johnson and Embley, 1990; Embley et al., 1990]. The South and North Rift Zones are oriented within $15^{\circ}$ of spreading direction and extend for $\sim 50 \mathrm{~km}$, overlapping with the neighboring Vance and Coaxial ridge segments (Figure 2b). The age difference between seamounts of the Cobb-Eickelberg chain and the underlying crust (estimated from radiometric age dating of seamount basalts and magnetic anomalies for underlying crustal age) diminishes eastward toward the JDFR, consistent with the northwestward advance of the ridge toward a stationary Cobb hot spot source [Desonie and Duncan, 1990]. Analysis of bathymetry and magnetic anomaly data indicate that Axial segment formed within the past $0.5 \mathrm{Ma}$ with an $\sim 20 \mathrm{~km}$ westward jump of the axis to 


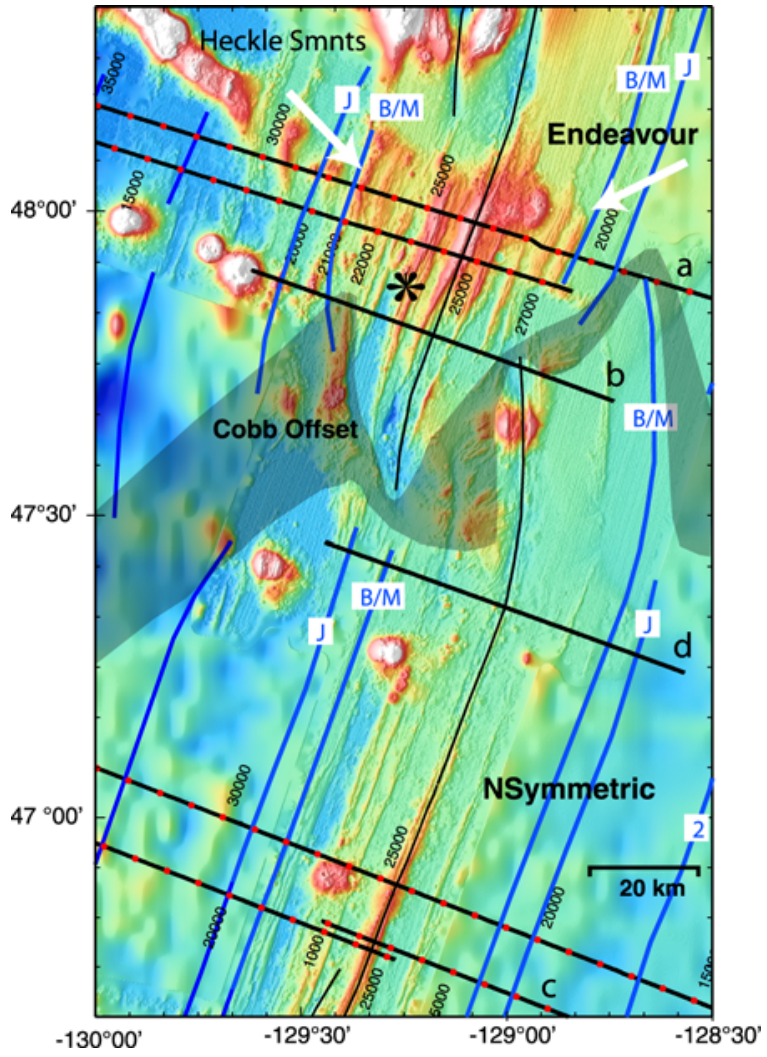

Figure 2a. Close-up bathymetric map of Endeavour and Northern Symmetric segments. Black mediumweight lines mark location of ridge axis; blue lines correspond to magnetic isochrons. Isochron labels in blue are B/M, Brunhes/Matuyama; J, Jaramilo; 2, anomaly 2 ; and $2 \mathrm{a}$, anomaly $2 \mathrm{a}$. Bold black cross-axis lines labeled a through d show locations of bathymetry profiles in Figure 2c selected to illustrate characteristic ridge morphology near the center and end of these two segments. Black bold lines with red dots marking every 1000 CMP correspond to ridge flank seismic profiles highlighted in Figure 1. White arrows point to the outward facing slopes that mark the boundaries of axiscentered plateau discussed in text. Black star indicates prominent west flank hill, which may be former ridge axis prior to small ridge jump to current location. Gray shading highlights approximate region of disturbed seafloor topography associated with recent history of dueling propagation of the Endeavour and Northern Symmetric segments (see text).

override the Cobb hotpot [Delaney et al., 1981; Tivey and Johnson, 1990]. Magnetic anomalies also indicate that both Vance and Coaxial did not exist as discrete segments from the neighboring Cleft and Northern Symmetric segments prior to the Brunhes anomaly and the current second-order segmentation of the JDFR formed since this time (Figure 1) [Wilson, 1993].
[7] The shallow central portion of Endeavour segment coincides with a broad region extending onto the ridge flanks that marks the projection of the Heckle seamount chain to the ridge axis (Figures 1 and 2a). On the basis of morphologic and geochemical observations, Karsten et al. [1986] and Karsten and Delaney [1989] suggest that current magma supply to this segment is influenced by the mantle anomaly associated with the Heckle seamounts. The youngest conical seamount edifice in the Heckle chain is $\sim 1.5 \mathrm{Ma}$. On younger crust, elongate seamount edifices and prominent elongate abyssal hills are observed, which lengthen with diminished age, indicating increasing interaction between the ridge axis and seamount melt source. Other small seamount chains in the region include the Heck chain adjacent to West Valley segment, Springfield seamounts west of Northern Symmetric

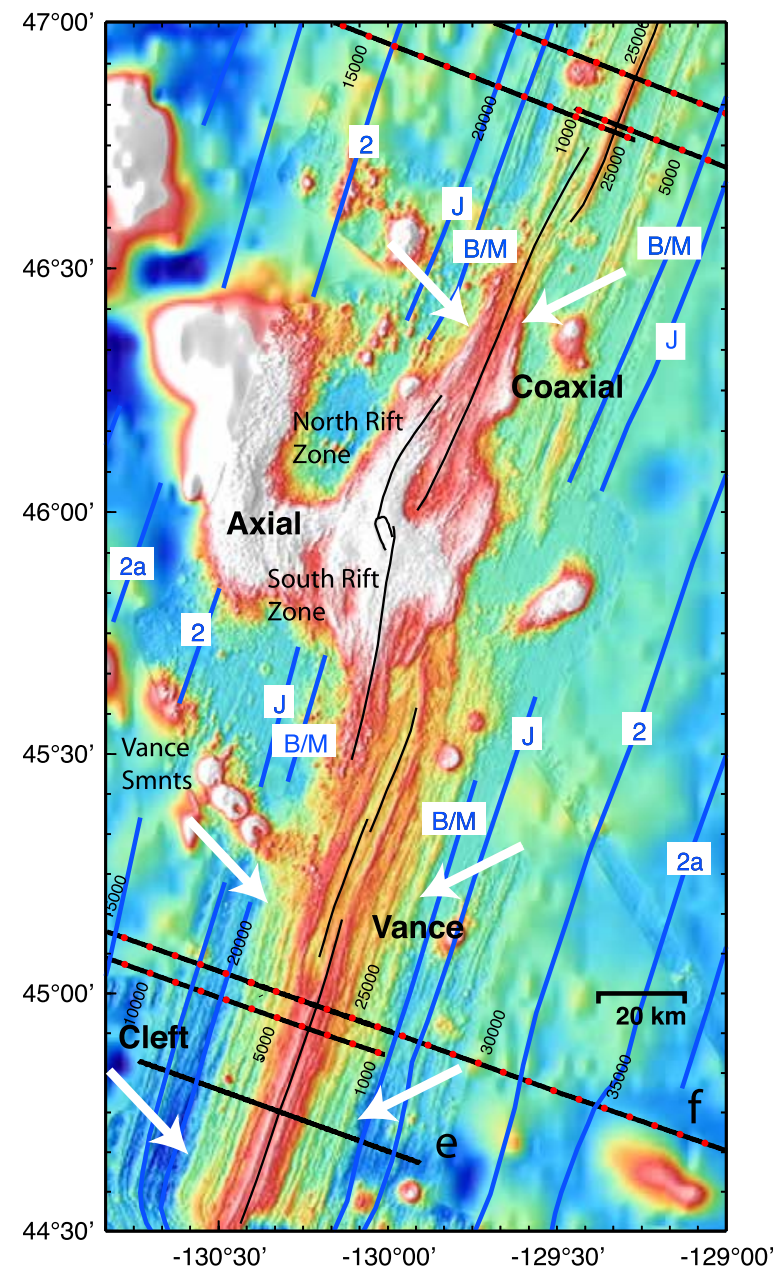

Figure 2b. Close-up bathymetric map from southern Northern Symmetric to Cleft segments. Annotation as in Figure 2a. 

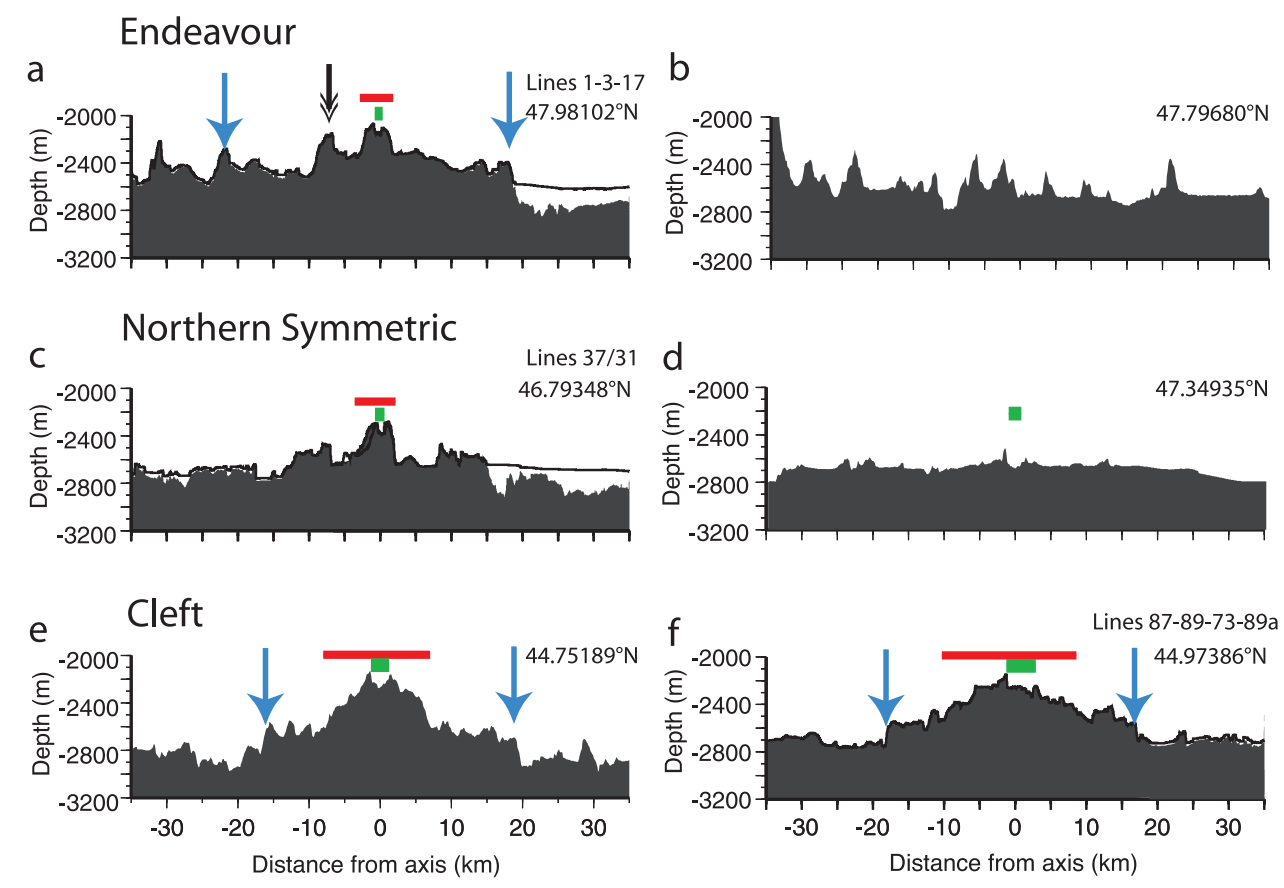

Segment shoal

Segment end

Figure 2c. Seafloor depth profiles comparing ridge axis morphology near (left) segment midpoints and (right) segment ends within Endeavour, Northern Symmetric, and Cleft segments (see Figures $2 \mathrm{a}$ and $2 \mathrm{~b}$ for profile locations). Profiles a, c, and f correspond to ridge flank seismic lines and show depth to top of oceanic crust as well as depth to seafloor. Sediment cover on the east flank of the ridge partially buries the crustal topography. Blue vertical arrows indicate edges of distinct plateau found at Cleft segment and within central Endeavour segment. Small black arrow indicates possible former ridge axis location prior to jump to current axis. Red horizontal bars show lateral extent of axial high where present. Green horizontal bars show lateral extent of shallow axial rift graben (see text).

segment, and the Vance seamounts near the southern end of Vance segment (Figure 1).

[8] The tectonic history of the JDFR over the past $18 \mathrm{Ma}$ is dominated by a series of ridge propagation events that have resulted in clockwise rotation of the ridge axis by $20^{\circ}$ in response to a changing direction of relative plate motion (Figure 1) [Wilson et al., 1984; Wilson, 1993]. Southward propagation of the ridge axis established the Blanco Transform Fault (TF) at approximately its current location by $\sim 5.8 \mathrm{Ma}$ [Wilson, 1993; Embley and Wilson, 1992]. Two more recent propagating events terminated at the Blanco TF and resulted in lengthening of the transform offset with the most recent phase ending at $1.4 \mathrm{Ma}$. Over the past several Ma, the location of the Blanco TF has jumped north with the most recent jump at $\sim 0.4 \mathrm{Ma}$, likely in response to the readjustment of the JDFR axis associated with rift propagation [Embley and Wilson, 1992]. Northward propagation of the Cobb offset, which separates Endeavour and Northern Symmetric segments, initiated at $\sim 4.5 \mathrm{Ma}$ [Wilson, 1993]. The Cobb offset reached its maximum northward extent at $\sim 0.8 \mathrm{Ma}$, then retreated to approximately $47^{\circ} 35^{\prime} \mathrm{N}$ as Endeavour segment propagated southward (Figure 2a) [Shoberg et al., 1991]. Propagation has reversed in the past 100,000 years, with the northern end of Northern Symmetric segment currently located at $47^{\circ} 46^{\prime} \mathrm{N}$.

\section{Data and Methods}

\subsection{Seismic Data}

[9] Multichannel seismic data were collected within three transects oriented perpendicular to the ridge axis crossing Endeavour, Northern Symmetric and Cleft segments and extending $\sim 150 \mathrm{~km}$ on each ridge flank (Figure 1). Along-axis seismic data also collected during the survey provide constraints on zero-age crustal structure. Seismic data were acquired using a 10 air gun tuned array with a source volume of $3005 \mathrm{cu}$. in., towed at a nominal depth of $7.5 \mathrm{~m}$, with shots fired every $37.5 \mathrm{~m}$ along track. Data were recorded using a 6-km-long 480 


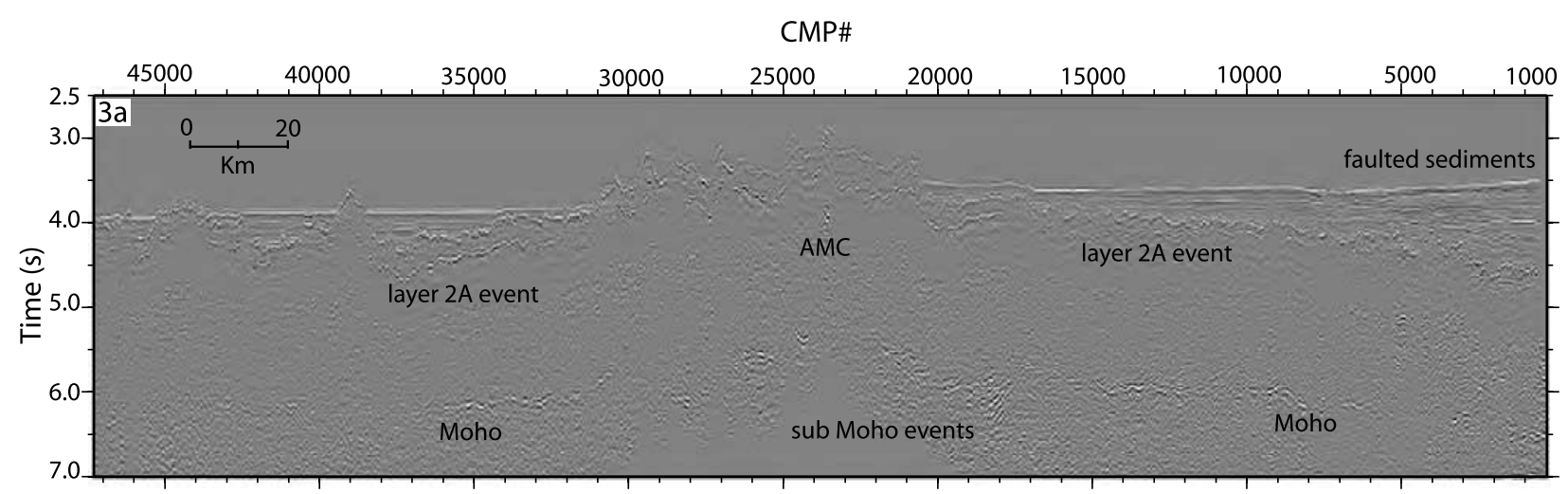

Figure 3a. Ridge flank composite seismic profile 1-3-17 crossing Endeavour segment with base of layer 2A event, axial magma lens, and Moho reflections labeled.

channel Syntron digital streamer with receiver groups spaced at $12.5 \mathrm{~m}$. Streamer depth (nominal $10 \mathrm{~m}$ ) and feathering were monitored with 13 depth controlling and 11 compass-enhanced DigiCourse birds, and a GPS receiver on the tail buoy. For the flank transects, data were recorded at a sampling frequency of $2 \mathrm{~ms}$ for 10.24-s-long records. The recorded signal has a bandwidth ranging from $\sim 2$ to over $100 \mathrm{~Hz}$ with a dominant frequency of $\sim 10-30 \mathrm{~Hz}$. Nominal common midpoint (CMP) gather spacing is $6.25 \mathrm{~m}$, providing a data trace fold of $\sim 80$.

[10] The prestack processing sequence for the reflection data includes F-K and bandpass (2-7 and $100-125 \mathrm{~Hz}$ ) filtering, amplitude correction for geometrical spreading, and trace editing, followed by CMP sort, velocity analysis, normal and dip move-out corrections to align the signal for stacking and CMP mute. The poststack processing includes seafloor mute, primary multiple mute to reduce migration noise, bandpass filtering (from $2-7$ to $100-125 \mathrm{~Hz}$ for shallow sediments to $2-7$ to $20-40 \mathrm{~Hz}$ at Moho depth) and time migration to collapse diffractions and correctly position reflections. Processing for the layer $2 \mathrm{~A} / 2 \mathrm{~B}$ event, a refracted arrival detected at large source-receiver offsets [e.g., Harding et al., 1993; Vera and Diebold, 1994] involves a modified processing sequence. Optimal normal move-out velocities that best flatten the retrograde branch of the $2 \mathrm{~A}$ refraction are chosen from constant velocity stacks. The stacked layer $2 \mathrm{~A}$ event is time migrated and coherency filtered. Surgical mute is then used to extract the layer $2 \mathrm{~A}$ event, which is merged with the reflection section to form the final, composite seismic image.
Full details on the data processing sequence are provided by Nedimovic et al. [2005b].

[11] From final migrated sections (Figures 3a, 3b, $3 \mathrm{c}$, and $3 \mathrm{~d}$ ) seafloor, top of oceanic crust, base of layer 2A, Moho, and the reflection from the top of the axial magma chamber (AMC) detected beneath the ridge axis are identified. Estimated picking errors are $0.03 \mathrm{~s}$ for top of oceanic crust and $\mathrm{AMC}$, and $0.04 \mathrm{~s}$ for the base of layer $2 \mathrm{~A}$ and Moho. Crustal ages along each seismic profile are interpolated from Wilson [1993]. Interpreted ridge flank structure is shown in Figures 4a, 4b, and 4c. Along Endeavour and Northern Symmetric transects, two-way traveltimes (TWTT) to the layer 2A event are systematically lower on the east flank because of eastward increase in seismic velocities within layer 2A. Higher velocities are attributed to enhanced upper crustal alteration associated with thick sediment cover, which blankets the Juan de Fuca plate in this region (Nedimović et al., submitted manuscript, 2008). Because of this marked asymmetry in layer 2A structure, both TWTT to Moho from top of the oceanic crust (Moho $\left.{ }_{\text {crust }}\right)$ and from the layer $2 \mathrm{~A}$ event $\left(\mathrm{Moho}_{2 \mathrm{~A}} \mathrm{~A}\right)$ are included in Figures $4 a-4 c$.

[12] Zero-age crustal properties for each ridge segment including ridge axis depth, on-axis $2 \mathrm{~A}$ thickness, AMC depth, and percent of segment with a detectable AMC, are shown in Figures 5 and 6 and summarized in Table 1.

\subsection{Bathymetric Data}

[13] Bathymetry data used in this study are from the Global MultiResolution Topography synthesis (available at http://www.marine-geo.org/services/ 


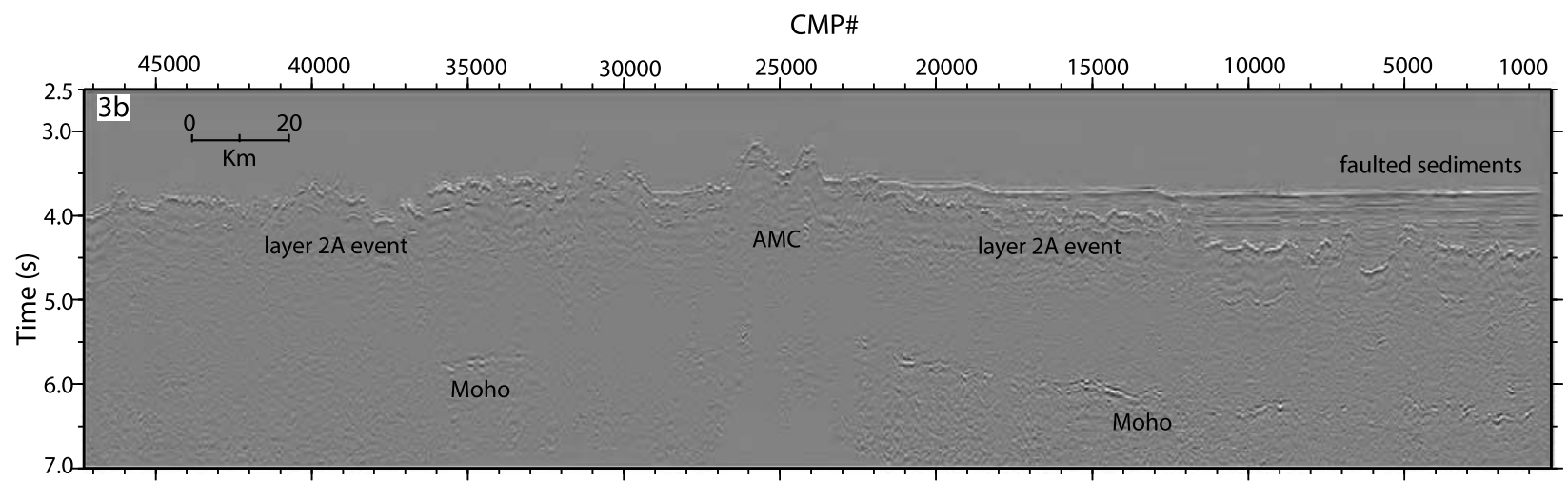

Figure 3b. Ridge flank composite seismic profile 32-34 crossing Northern Symmetric segment with base of layer 2A event, axial magma lens, and Moho reflections labeled.

google/create merc map.php). In the JDFR region, the original data sources for the compilation include Hydrosweep multibeam bathymetric data collected simultaneous with our seismic survey and during the 1999 seismic study at Axial Volcano [West et al., 2001], Simrad EM300 data for the axial region of Cleft segment collected by MBARI [Stakes et al., 2006], and an extensive NOAA Seabeam data set collected under the NOAA PMEL Vents program (provided by A. Bobbit). Data are weighted on the basis of data quality (e.g., EM300 data is used preferentially where available) and gridded at a node interval of $\sim 200 \mathrm{~m}$.

\section{Results}

\subsection{Seafloor Structure}

[14] Each JDFR segment is characterized by a distinct axial morphology with a shallow (100$200 \mathrm{~m}$ ) rift or graben located at the center of a broader 5-15 $\mathrm{km}$ wide, 100-400 $\mathrm{m}$ axial high (Figure 2c) similar to that found on the fast spreading East Pacific Rise (EPR). The shallow axial graben appears to be a magmatic rather than tectonically generated structure, linked to dike intrusion and magma withdrawal from the midcrust magma lens found at depths of $2-3 \mathrm{~km}$ along this ridge [Carbotte et al., 2006]. As a magmatically generated depression linked to the presence of a crustal magma body, the axial graben is more similar to the axial summit trough (AST) at the EPR, than to the axial valley found along slow spreading ridges which forms largely by amagmatic extension. However, the axial graben along the JDFR differs from the AST at the EPR in that it is a fault bounded structure rather than a volcano collapse drain-back feature [Fornari et al., 1998] with the structural differences likely due to the thicker brittle layer and longer time intervals between intrusions at the slower spreading JDFR.

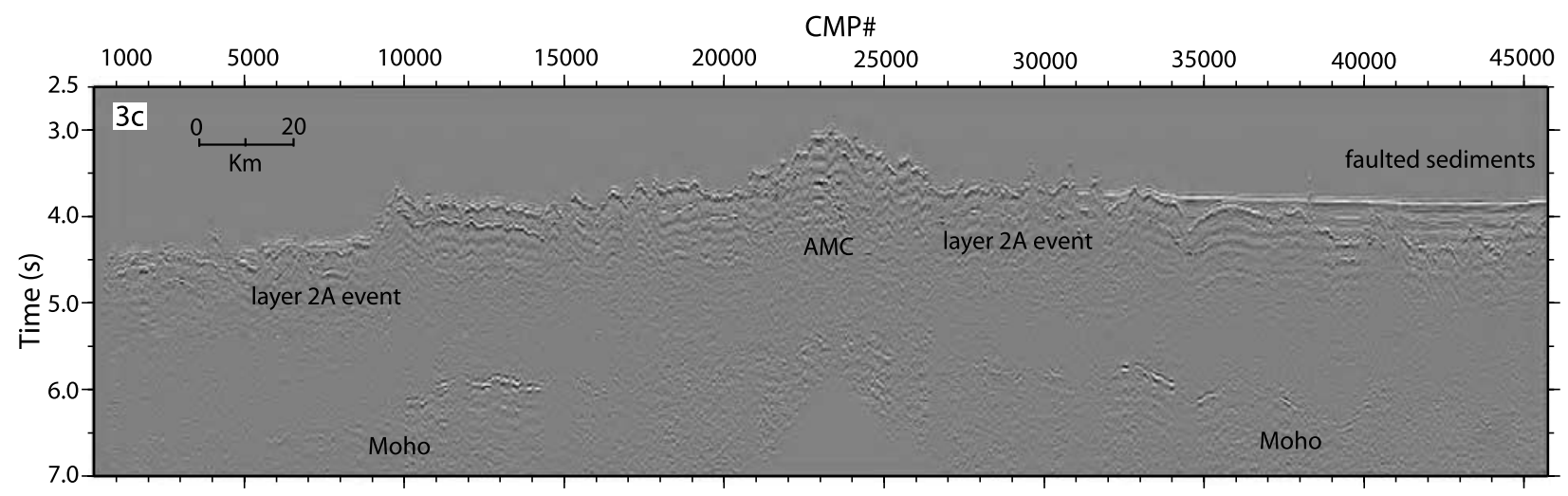

Figure 3c. Ridge flank composite seismic profile 87-89-73-89a crossing Cleft segment with base of layer 2A event, axial magma lens, and Moho reflections labeled. 


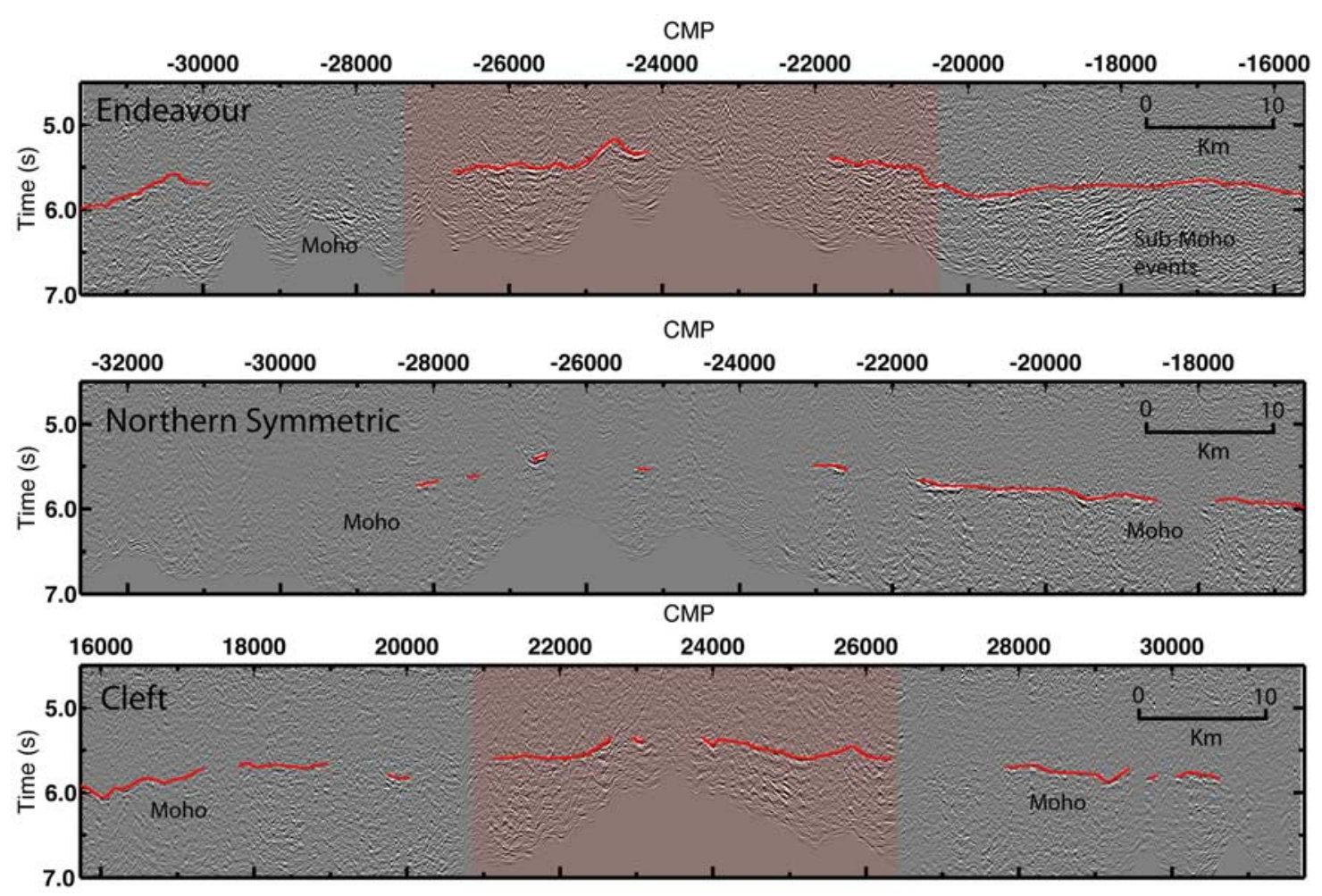

Figure 3d. Close-up of Moho event along each transect within the inner $50 \mathrm{~km}$ of the ridge axis. Thin red line shows our picked Moho locations. Red shaded region corresponds to axis-centered plateau at Cleft and Endeavour segments highlighted in Figures $4 \mathrm{a}-4 \mathrm{c}$.

[15] These segment-to-segment changes in the morphology of the axial graben are superimposed on longer-wavelength south-to-north gradients in ridge structure with a deeper ridge axis, narrower axial high and more variable ridge structure to the north. Average ridge axis depth for each segment increases to the north (Figure 6) and within all segments except Endeavour, the ridge axis is shallowest at its southern end (Figure 5). Axial Volcano and the central portion of Endeavour segment are both localized shallow regions along the ridge axis, proximal to nearby seamount chains, which are superimposed on the long-wavelength northward deepening trend.

[16] The cross-axis width of the axial high and elevation above surrounding seafloor diminishes from south to north (Figures $2 \mathrm{a}-2 \mathrm{c}$ ). Whereas the axial high rises over $400 \mathrm{~m}$ above surrounding seafloor at Cleft segment, a more subdued high is present at Northern Symmetric and Endeavour segments $(100-300 \mathrm{~m})$. The axial high is widest at Cleft and Vance segments $(15 \mathrm{~km})$ compared with $\sim 5 \mathrm{~km}$ at Northern Symmetric and Endeavour segments (Figure 2c). Variability in ridge structure also increases to the north. Over the length of
Endeavour segment, axial depth varies by $800 \mathrm{~m}$, compared with less than $200 \mathrm{~m}$ at Cleft segment (Figures 5 and 6). Whereas a broad axial high is present along the length of Cleft segment with minor difference in cross-axis width and height (Figures $2 \mathrm{~b}$ and $2 \mathrm{c}$ ), the axial high diminishes and becomes difficult to identify toward the ends of Northern Symmetric and Endeavour segments (Figures $2 \mathrm{a}$ and $2 \mathrm{c}$ ).

[17] At both Cleft and Endeavour segments, the axial high is centered within a broader elevated plateau defined by prominent ridge-parallel outward facing slopes present on both sides of the axis that are up to several hundred meters higher than typical abyssal hill relief (50-100 m, Figures 2a$2 \mathrm{c}$ and $4 \mathrm{a})$. At Cleft segment, conjugate outward facing slopes define a plateau that is $200-300 \mathrm{~m}$ high and $32 \mathrm{~km}$ wide centered about the axis, which extends for the full length of the segment. At Endeavour segment the eastern plateau edge coincides with a partially sediment buried scarp $350 \mathrm{~m}$ high located $18 \mathrm{~km}$ from the axis. This scarp marks the transition from sediment-free to sediment-covered basement and is identified as an important hydrogeologic boundary in ODP-IODP 

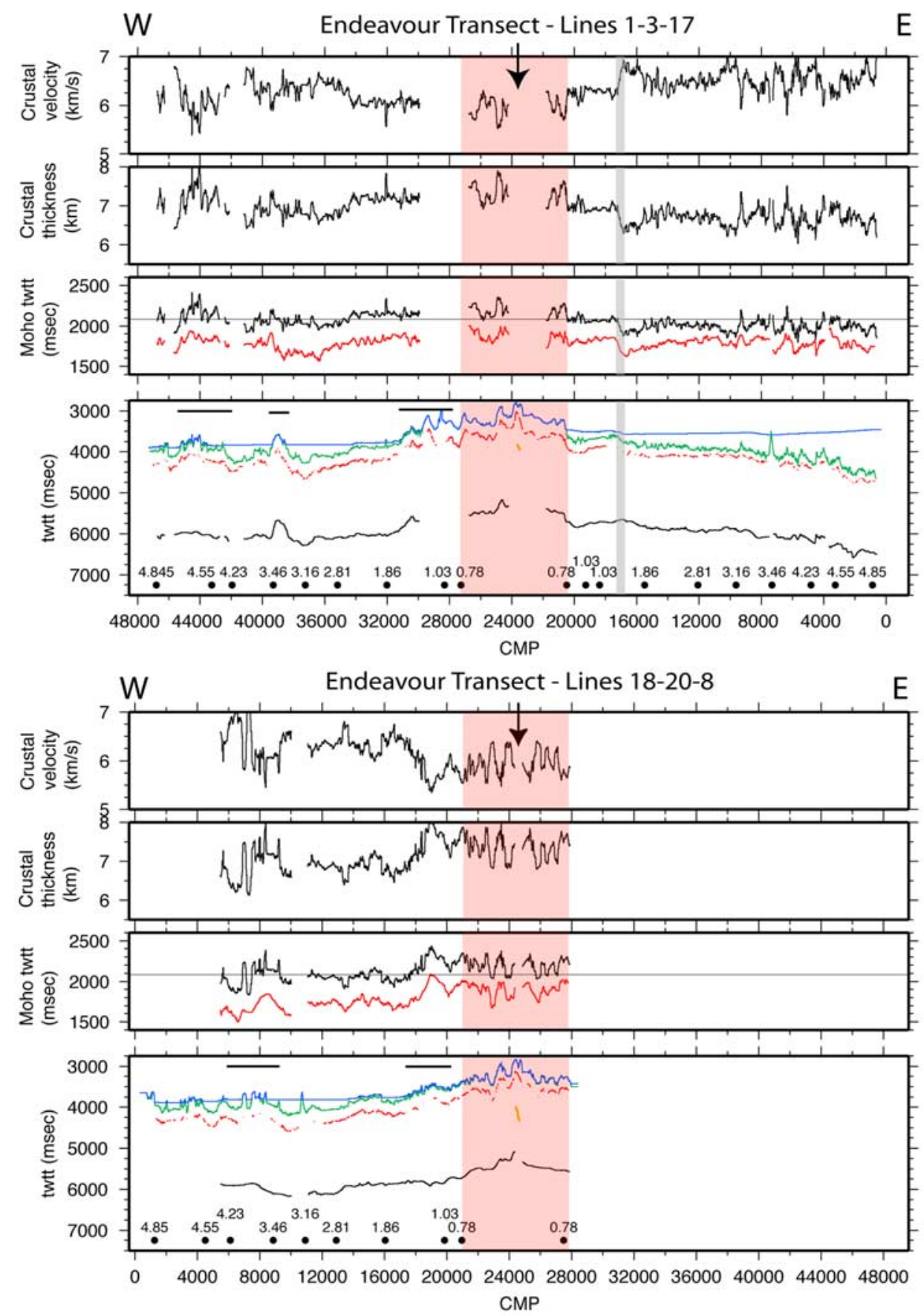

Figure 4a. Line drawing interpretations of seismic horizons detected along both composite seismic profiles within the Endeavour segment transect. For each seismic profile, bottom plot shows two-way traveltime to seafloor (blue), top of oceanic crust (green), base of layer 2A (red), axial magma chamber reflection at axis (AMC, orange), and Moho (black). The third plots show traveltime to Moho measured from top of oceanic crust (Moho $\mathrm{crust}_{\text {, }}$ black) and from base of layer 2A event $\left(\mathrm{Moho}_{2 \mathrm{a}}\right.$, red). Thin black horizontal line indicates the average Moho $\mathrm{Mrust}_{\mathrm{TWT}}$ TW $2090 \mathrm{~ms}$ obtained for all three transects (see text). The second plots show variations in crustal thickness calculated from Moho traveltimes assuming a uniform crustal velocity of $6.7 \mathrm{~km} / \mathrm{s}$. The top plots show inferred crustal velocity calculated assuming uniform crustal thickness of $6.5 \mathrm{~km}$ for profile. Vertical black arrows show location of axis. Red shading indicates extent of interpreted $40 \mathrm{~km}$ wide plateau-bounding axis at Endeavour segment. Light gray shading indicates location of propagator psuedofault crossing also shown in map view in Figure 1. Crustal ages in Ma from Wilson [1993] are indicated along each profile in the bottom plots with labeled black dots. Black horizontal lines in the same plot highlight locations of seamounts and the region of presumed seamount source-influenced crust west of the current Endeavour axis. 

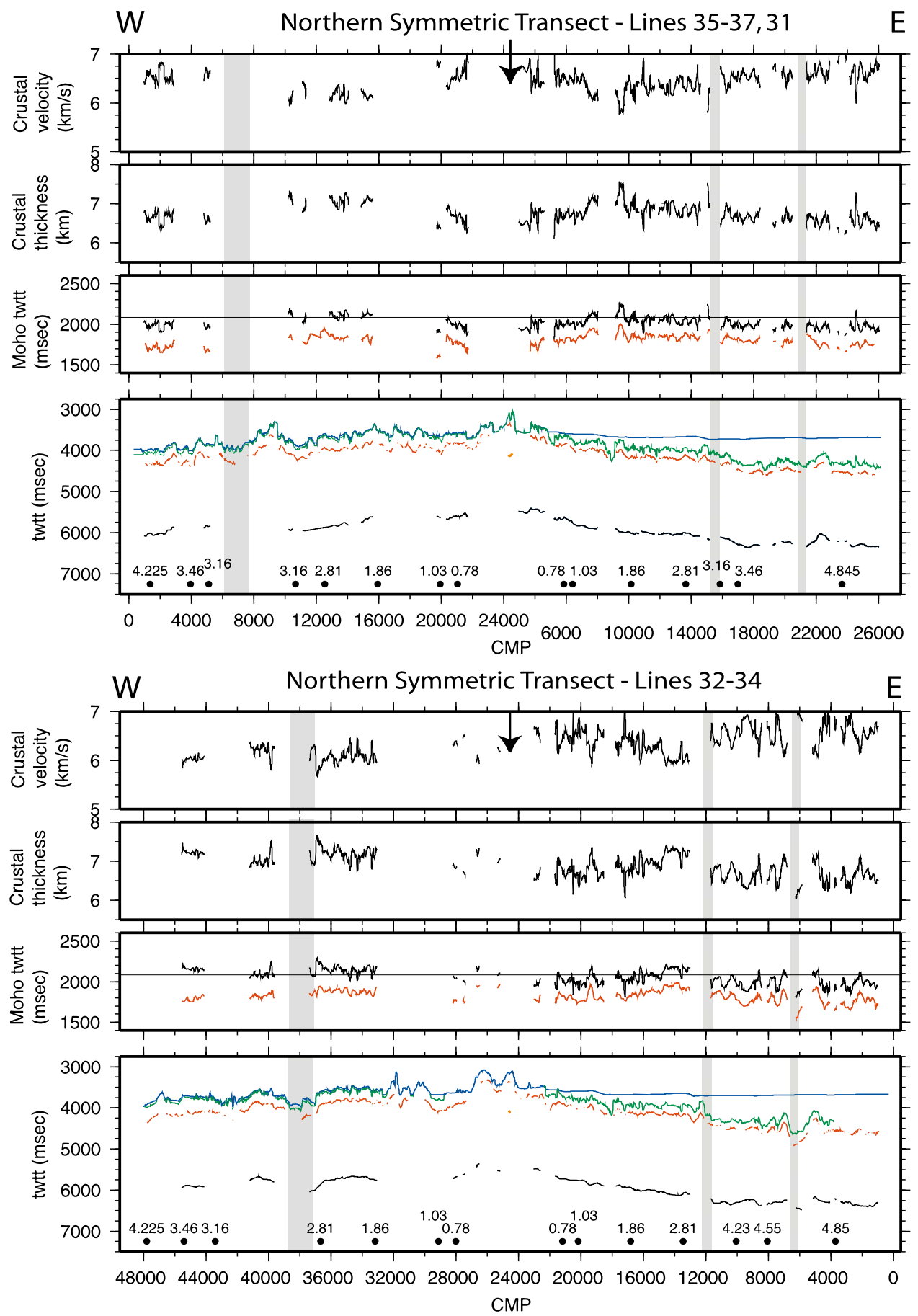

Figure 4b. Line drawing interpretations of seismic horizons detected along both composite seismic profiles within the Northern Symmetric segment transect. Annotation as in Figure 4a.

FlankFlux studies [Davis et al., 1992]. The western plateau boundary is $\sim 300 \mathrm{~m}$ high and is located further from the axis $(21 \mathrm{~km})$. The Endeavour plateau is limited to the central southern portion of the segment and varies in along-axis length, consistent with lengthening of Endeavour segment during the Brunhes by southward propagation (Figure 2a).

\subsection{Shallow to Midcrust Structure}

[18] Regional south to north gradients in subseafloor structure are evident in along-axis seismic 

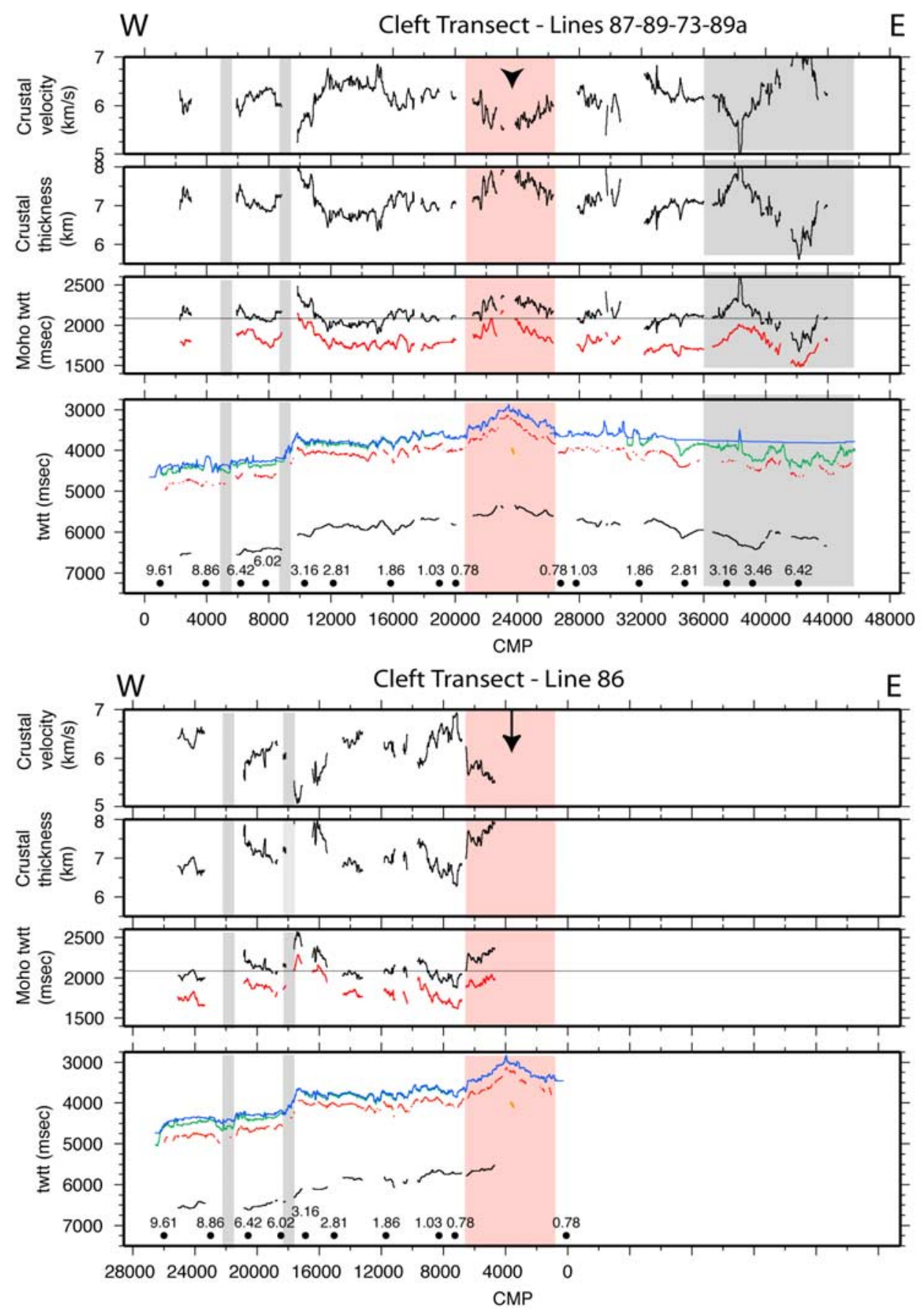

Figure 4c. Line drawing interpretations of seismic horizons detected along both composite seismic profiles within the Cleft segment transect. Red shading indicates extent of interpreted $32 \mathrm{~km}$ wide plateau bounding axis of Cleft segment. Rest of annotation as in Figure 4a.

data, consistent with the regional gradients observed in seafloor properties. The depth of the $\mathrm{AMC}$ reflection varies from segment to segment with the shallowest (excluding Axial) and most uniform depths found beneath Cleft segment and the deepest and most variable AMC beneath En- deavour segment (Figure 6) [Carbotte et al., 2006]. Within most segments, the AMC is shallowest at the southern end of the segment, deepening to the north, also consistent with trends in seafloor depth (Figure 5). The proportion of each segment with a detected AMC varies along the JDFR; whereas an 
a
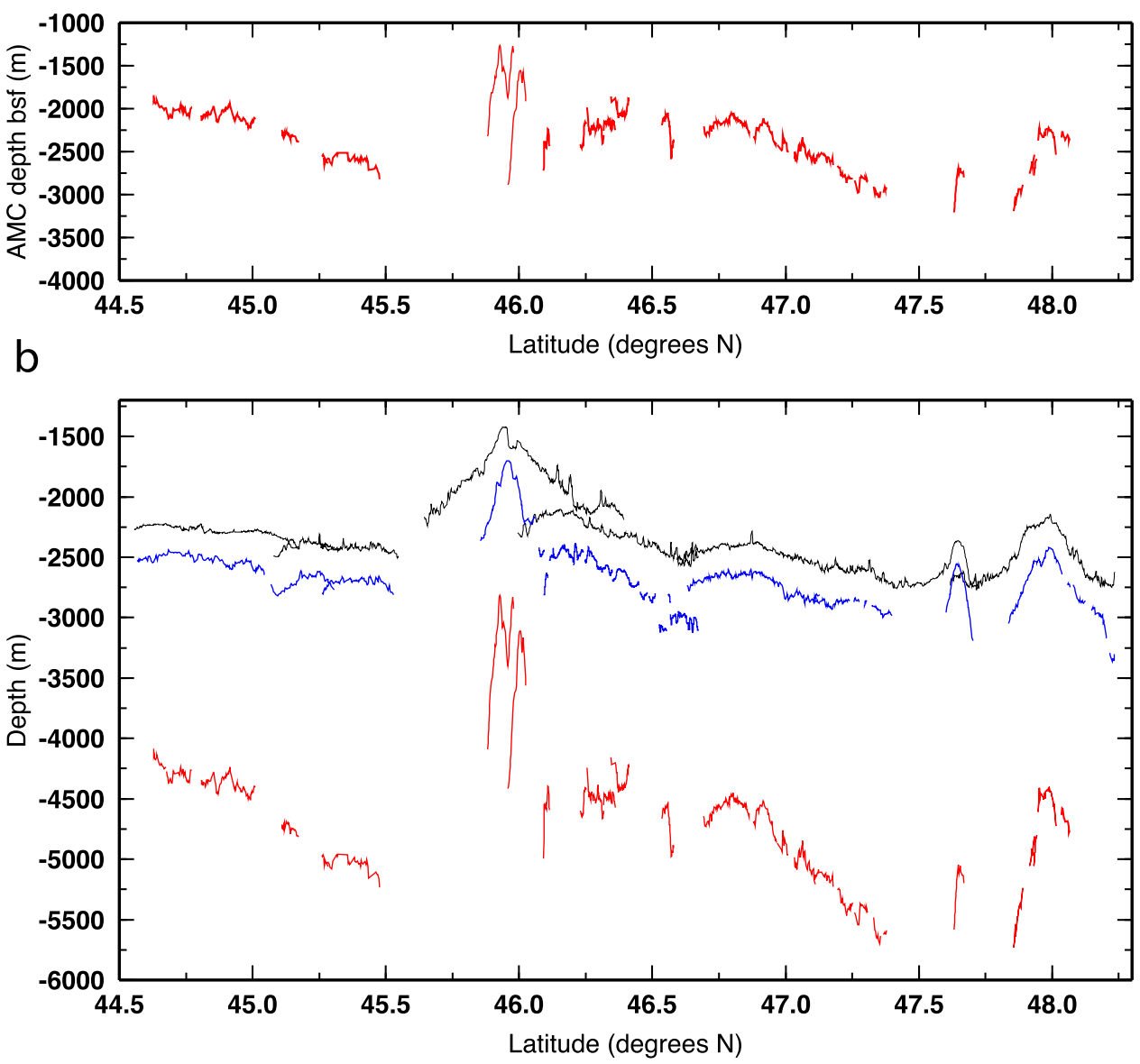

Figure 5. Interpretation of zero-age axial structure along the JDFR from along-axis seismic profiles. (a) AMC depth below seafloor. Depths are calculated from reflection traveltimes using velocities of $2.26 \mathrm{~km} / \mathrm{s}$ for layer $2 \mathrm{~A}$ and $5.5 \mathrm{~km} / \mathrm{s}$ for layer 2B. (b) Along-axis profile showing depth to seafloor (black), base of layer 2A (blue), and axial magma chamber reflection (AMC) (red). Figure is modified from Carbotte et al. [2006] and includes data from Axial Volcano [Kent et al., 2003].

AMC is imaged beneath $68 \%$ of Cleft segment, it is present beneath only the central southern $21 \%$ of Endeavour segment (Table 1).

[19] The thickness of layer 2A varies from segment to segment. Along the ridge axis, the thinnest and most uniform 2A is found at Cleft segment with the thickest and most variable 2A beneath Endeavour segment. Within all segments, seismic layer $2 \mathrm{~A}$ is thinnest where the AMC is detected and thickens toward segment ends where the magma lens disappears, similar to observations at other ridges [e.g., Kent et al., 1994; Carbotte et al., 2000]. Along the ridge flank transects, layer $2 \mathrm{~A}$ is thickest at Endeavour segment with similar average values at Cleft and Northern Symmetric segments (Table 2). Detailed ridge axis surveys show that layer 2A thickness increases within $3-5 \mathrm{~km}$ of the axis at Cleft segment whereas minor off-axis thickening is observed at Endeavour segment [Canales et al., 2005; Van Ark et al., 2007].

\subsection{Moho Structure}

[20] Moho is well imaged on all profiles and can be identified as close as $1-3 \mathrm{~km}$ from the ridge axis at each segment (Table 2 and Figures $3 \mathrm{a}-3 \mathrm{~d}$ and $4 \mathrm{a}-$ $4 c)$, indicating formation at earliest crustal ages similar to inferences from the EPR [e.g., Singh et al., 2006]. However, Moho presence and depth within the near axis region differ at the 3 segments. At Endeavour and Cleft segments Moho is present within $40-60 \%$ of the innermost $20 \mathrm{~km}$ at an average TWTT of $2190 \pm 90$ and $2300 \pm 40 \mathrm{~ms}$ respectively. In contrast, at Northern Symmetric segment Moho is only detected beneath $20 \%$ of the innermost $20 \mathrm{~km}$ and Moho traveltimes are $\sim 200-300 \mathrm{~ms}$ lower (Table 2). Scattering associated with the rough 
a

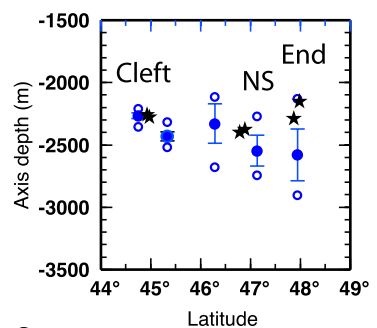

C
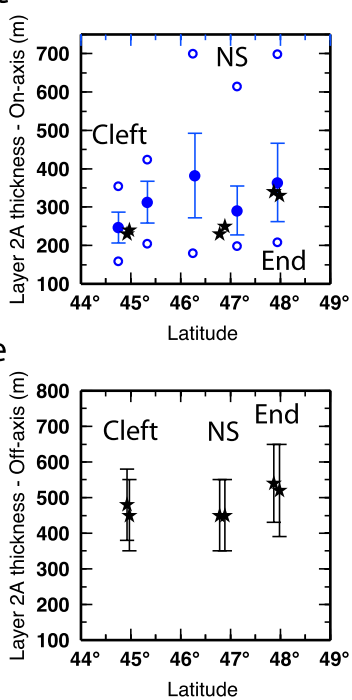

b

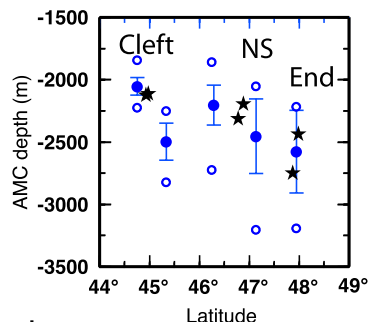

d

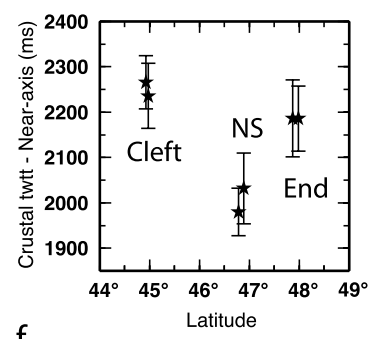

$f$

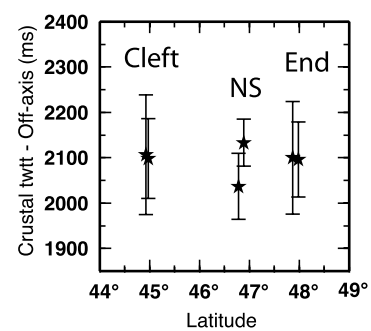

Figure 6. Comparison of $(a-d)$ on-axis and (e and $f$ ) off-axis crustal structure within individual ridge segments of the JDFR. For all plots, filled solid stars indicate averages measured from ridge flank transects at Endeavour (End), Northern Symmetric (NS), and Cleft segments and plotted at latitude of axis crossing for each profile. (a) Ridge axis depth, (b) AMC depth, and (c) on-axis layer 2A thickness. Solid circles in Figures 6a$6 \mathrm{c}$ correspond to segment average measured from alongaxis seismic profiles shown in Figure 5 and plotted at latitude of segment midpoint with 1 standard deviation (bars) and total range (open circles) of values for each segment (values also given in Table 1). Measurements for ridge flank transects (stars) correspond with average traveltimes within $\pm 1 \mathrm{~km}$ of axis crossing and converted to depth using $\mathrm{Vp}=2.26 \mathrm{~km} / \mathrm{s}$. (d) Average near-axis crustal thickness (TWTT) measured from flank transects within $20 \mathrm{~km}$ of the axis. (e) Average off-axis layer 2A thickness, measured beyond $1 \mathrm{~km}$ from axis crossing and converted to depth using $\mathrm{Vp}=3.2 \mathrm{~km} / \mathrm{s}$. Data from the east flank are excluded because of variable $2 \mathrm{~A}$ structure associated with sediment burial (see text). (f) Average offaxis crustal thickness (TWTT) measured beyond $20 \mathrm{~km}$ from axis (west flank only).

unsedimented axial seafloor presumably contributes to intermittent imaging of Moho at all segments. However, as seafloor relief is comparable at the three segments, the observed differences in Moho presence are unlikely to be due solely to

seafloor scattering effects and possible differences in the nature of the crust-mantle transition zone are implied.

[21] Further on the ridge flanks, average Moho TWTT is similar for all three segments $(\sim 2100 \mathrm{~ms})$. Accounting for differences in layer $2 \mathrm{~A}$ thickness, average traveltimes to Moho $\left(\mathrm{Moho}_{2 \mathrm{~A}}\right)$ differ by less than $35 \mathrm{~ms}$ (within the resolution limits of our data). In general, Moho is detected beneath more of the eastern flank of the ridge than the western flank, likely because of improved imaging conditions associated with the thick sediment cover to the east (Figures $3 a-3 c$ and $4 a-4 c$ ).

[22] The transition from greater near-axis Moho traveltimes at Endeavour and Cleft (2190 and $2300 \mathrm{~ms}$ respectively, Table 2) to lesser ridge flank values $(2100 \mathrm{~ms})$ coincides with the edges of the broad, axis-centered plateaus observed at both of these segments. Steps in Moho TWTT coincident with the plateau's bounding slopes are evident on line 86 at Cleft segment (Figure 4c) and on the eastern plateau crossing of line 1-3-17 at Endeavour (Figure 4a). Longer Moho TWTT persist beyond the western plateau boundary at Endeavour and are associated with the elongate Heckle seamounts (line 18-20-8). Seismic data from additional survey lines within Endeavour segment (Figure 1) [Van Ark et al., 2007] show that the high near-axis Moho TWTT are restricted to the plateau region confined to the central south portion of the segment. North and south of the plateau, a shorter Moho TWTT of $\sim 2100 \mathrm{~ms}$ is measured within the near axis region comparable to average ridge flank values (E. Van Ark, personal communication, 2007). Seismic lines from the detailed Cleft segment survey are presented by Canales et al. [2005] and show that high Moho TWTT of 2200-2400 ms underlie the length of the $30 \mathrm{~km}$ wide plateau at this segment. High Moho traveltimes persist to the southern end of Cleft segment with a bright Moho at $2400 \mathrm{~ms}$ below seafloor evident along line 41 located only $15 \mathrm{~km}$ from the southern termination of the segment [see Canales et al., 2005, Figure 8].

[23] Along all flank transects, local Moho traveltime anomalies (100 to $500 \mathrm{~ms}$ greater than average Moho traveltimes) are observed on the young crust side of propagator wakes (Figures $4 a-4 c$ ). Within pseudofault zones, Moho is weak to absent. The largest Moho traveltime anomalies are observed along the Cleft transect associated with the youngest southward propagator into the Blanco TF. A variety of factors may contribute to these elevated Moho traveltimes including thicker crust, slower 
Table 1. Ridge Segment Characteristics

\begin{tabular}{|c|c|c|c|c|c|c|}
\hline Segment & $\begin{array}{c}\text { Average } \\
\text { Ridge Axis } \\
\text { Depth }^{\mathrm{a}}(\mathrm{m})\end{array}$ & $\begin{array}{c}\text { Average } \\
\text { Layer 2A } \\
\text { Thickness } \\
\text { on Axis }^{b}(\mathrm{~m})\end{array}$ & $\begin{array}{c}\text { Average } \\
\text { AMC Depth } \\
\text { Below } \\
\text { Seafloor }^{\mathrm{b}}(\mathrm{m})\end{array}$ & $\begin{array}{l}\text { Length of } \\
\text { Segment } \\
\quad(\mathrm{km})\end{array}$ & $\begin{array}{l}\text { Length of } \\
\text { Segment } \\
\text { With } \\
\text { Detected } \\
\text { AMC }^{\text {d }}(\mathrm{km})\end{array}$ & $\begin{array}{c}\text { Percentage of } \\
\text { Segment With } \\
\text { Detected } \\
\text { AMC }^{\mathrm{d}}(\%)\end{array}$ \\
\hline Endeavour & $2579(208)$ & $364(102)$ & $2580(330)$ & 90 & 19 & 21 \\
\hline Northern Symmetric & $2546(123)$ & $291(64)$ & $2455(300)$ & 138 & 76 & 55 \\
\hline Coaxial & $2329(157)$ & $382(110)$ & $2206(160)$ & 74 & 36 & 49 \\
\hline Vance & $2431(37)$ & $313(54)$ & $2498(150)$ & 76 & 40 & 53 \\
\hline Cleft & $2266(24)$ & $247(40)$ & $2055(70)$ & 60 & 41 & 68 \\
\hline
\end{tabular}

${ }^{\mathrm{a}}$ Depth averages are calculated from evenly spaced along-axis bathymetric profiles digitized using GeoMapApp and the $\sim 200 \mathrm{~m}$ node bathymetric grid of the Global MultiResolution Topography synthesis (www.geomapapp.org). The value in parentheses is the standard deviation.

${ }^{\mathrm{b}}$ Segment averages are measured from along-axis seismic data shown in Figure 5 and are plotted in Figure 6. The value in parentheses is the standard deviation.

${ }^{c}$ Ridge segment lengths are measured along digitized ridge axis and include zone of segment overlap where present.

d Length of ridge segment with detected AMC represents a minimum value that may underpredict occurrence because of deviations of ship track above a narrow AMC

crustal velocities due to the presence of iron enriched crustal rocks [e.g., Iturrino et al., 1991], or more fractured and altered crust and possibly upper mantle. Elsewhere on the ridge flanks local Moho traveltime anomalies (up to $200 \mathrm{~ms}$ ) are associated with seamounts including the flanks of the Heckle seamounts along the Endeavour transect and a near-axis seamount west of the axis along the Northern Symmetric transect (Figures $4 \mathrm{a}$ and $4 \mathrm{~b}$ ). In addition to these regional variations, fluctuations in Moho TWTT on the order of 50-100 ms occur on the $5-10 \mathrm{~km}$ length scale of the abyssal hill relief, with greater traveltimes common beneath abyssal hills.

\section{Constraints on Crustal Velocities}

[24] Reflection data reveal similar average Moho traveltimes on the flanks of the three ridge seg- ments $(2100 \pm 100 \mathrm{~ms})$ beyond $20 \mathrm{~km}$ from the axis. In contrast, crustal traveltimes differ by up to $300 \mathrm{~ms}$ in the near-axis region, and require significant differences in crustal thickness and/or velocity in young crust (Figures $4 a-4 c$ and 6). Refraction studies conducted in the region since the 1980s provide some constraints on crustal thickness and seismic velocities relevant for interpreting the reflection results (Figure 7). On the ridge flanks, refraction data have been acquired east of Endeavour segment [McClymont and Clowes, 2005] and at Cleft segment north of the Blanco FZ centered $\sim 130^{\circ} \mathrm{W}$ and $44^{\circ} 26^{\prime} \mathrm{N}$ [Christeson et al., 2007]. In both regions, similar crustal thickness $(6.7-7.0 \mathrm{~km})$ is observed for normal crust away from the propagator wakes, consistent with the reflection data. Refraction data from the flanks of Northern Symmetric segment are available from the early experiment of McClain and Lewis [1982]. Much thinner

Table 2. Average Layer 2A and Crustal Properties for Three Segment Transects

\begin{tabular}{|c|c|c|c|c|c|c|c|c|}
\hline \multirow[b]{2}{*}{ Segment $^{\mathrm{a}}$} & \multicolumn{4}{|c|}{ Near Axis } & \multicolumn{2}{|c|}{ Off-Axis West Flank } & \multicolumn{2}{|c|}{ Off-Axis East Flank } \\
\hline & $\begin{array}{c}2 \mathrm{~A} \\
\mathrm{TWTT}^{\mathrm{b}} \\
(\mathrm{ms})\end{array}$ & $\begin{array}{c}\text { Moho }_{\text {crust }} \\
\text { TWTT }^{\mathrm{c}} \\
(\mathrm{ms})\end{array}$ & $\begin{array}{l}\text { Percent Near- } \\
\text { Axis Region } \\
\text { With Detected } \\
\text { Moho }^{c}(\%)\end{array}$ & $\begin{array}{c}\text { Distance } \\
\text { From Axis to } \\
\text { First Detected } \\
\text { Moho } \\
\text { Reflection } \\
(\mathrm{km})\end{array}$ & $\begin{array}{c}2 \mathrm{~A} \\
\mathrm{TWTT}^{\mathrm{b}} \\
(\mathrm{ms})\end{array}$ & $\begin{array}{c}\text { Moho }_{\text {crust }} \\
\text { TWTT }^{c} \\
(\mathrm{~ms})\end{array}$ & $\begin{array}{c}2 \mathrm{~A} \\
\mathrm{TWTT}^{\mathrm{b}} \\
(\mathrm{ms})\end{array}$ & $\begin{array}{l}\text { Moho }_{\text {crust }} \\
\text { TWTT }^{c} \\
(\mathrm{~ms})\end{array}$ \\
\hline Endeavour & $300 \pm 100$ & $\begin{aligned} 2190 & \pm 90 \\
(2190 & \pm 80)\end{aligned}$ & 57 & $1.5-11$ & $330 \pm 80$ & $2100 \pm 110$ & $240 \pm 90$ & $2010 \pm 70$ \\
\hline Northern Symmetric & $210 \pm 30$ & $\begin{array}{c}1980 \pm 50 \\
(1990 \pm 60)\end{array}$ & 21 & $3.3-17$ & $280 \pm 60$ & $2090 \pm 60$ & $210 \pm 50$ & $2020 \pm 80$ \\
\hline Cleft & $210 \pm 20$ & $\begin{aligned} 2300 & \pm 40 \\
(2250 & \pm 70)\end{aligned}$ & 42 & $1.2-6.9$ & $290 \pm 60$ & $2100 \pm 110$ & $340 \pm 70$ & $2090 \pm 150$ \\
\hline
\end{tabular}




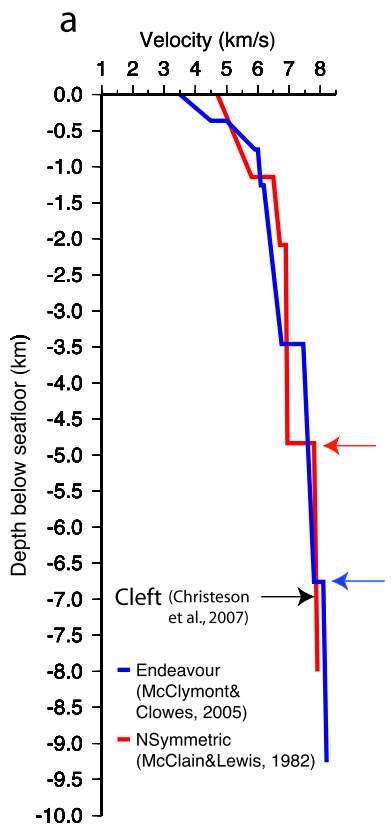

Ridge Flank Models

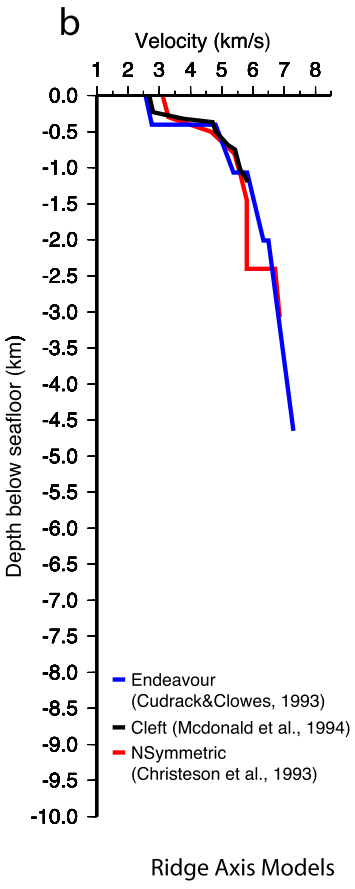

Ridge Axis Models
Figure 7. Compilation of velocity models obtained from previous seismic refraction studies within Cleft, Northern Symmetric, and Endeavour segments. (a) Velocity models for ridge flank crust at Endeavour [McClymont and Clowes, 2005] and Northern Symmetric [McClain and Lewis, 1982]. Horizontal arrows indicate crustmantle boundary. Depth to Moho from the recent reflection/refraction study of Christeson et al. [2007] at Cleft segment is indicated with black arrow. (b) Velocity models for axial crust from refraction studies of Cudrack and Clowes [1993] at Endeavour, Christeson et al. [1993] at Northern Symmetric, and McDonald et al. [1994] at Cleft.

crust $(5 \mathrm{~km})$ is reported, but with the sparse sampling of the mantle caustic obtained in this study, this value is poorly constrained. The data are also inconsistent with our coincident MCS data, which reveal a prominent Moho reflection at $\sim 2 \mathrm{~s}$ TWTT, much longer than predicted from their velocity model $(1.5 \mathrm{~s})$.

[25] Some constraints on seismic velocities in the axial region near all three transects are also available (e.g., Cudrack and Clowes [1993] and Barclay and Wilcock [2004] for Endeavour, Christeson et al. [1993] for Northern Symmetric, and McDonald et al. [1994] for Cleft). These studies have limited resolution within the shallowest crust, but indicate similar structure for the upper $1 \mathrm{~km}$ at the three segments, and a lower-velocity, thinner layer 2A on axis compared with off axis, consistent with the reflection data (Figure 7). Information on seismic velocities for the lower crust in the on- or near-axis region is not available in any of these three areas.

\section{Discussion}

[26] Additional constraints on lower crustal structure will be needed to establish whether greater Moho TWTT beneath the $32-40 \mathrm{~km}$ wide axiscentered plateau at Cleft and Endeavour reflect thicker crust or slower seismic velocities and both may plausibly contribute. The magnitude of traveltime anomalies associated with these plateau require $0.5-1.0 \mathrm{~km}$ thicker crust or seismic velocities that are 0.6 and $0.9 \mathrm{~km} / \mathrm{s}$ slower within Layer 2B/3 (Figures $4 \mathrm{a}-4 \mathrm{c}$ ). Assuming that crustal velocities depend on temperature as $d V / d T=-0.76$ $10^{-3} \mathrm{~km} \mathrm{~s}^{-1} \mathrm{~K}^{-1}$ [Christensen, 1979], slower velocities by $0.6-0.9 \mathrm{~km} / \mathrm{s}$ would require excess crustal temperatures of $\sim 800-1,200^{\circ} \mathrm{C}$ beneath these plateau regions relative to further on the ridge flanks. Although such temperature anomalies are expected at the ridge axis, seismic tomography studies at the faster spreading EPR suggest that the lower crust is quickly cooled by hydrothermal circulation and that significant thermal anomalies do not extend beyond 4-6 km off axis [Dunn et al., 2000]. For the same reason, partial melt is not expected to be present outside of the axial hightemperature region. From these observations at the EPR, the $32-40 \mathrm{~km}$ wide region of greater Moho traveltimes at Endeavour and Cleft appears too wide to be attributed to axial temperature anomalies alone. There is evidence for off-axis volcanism at Cleft segment including young constructional mounds and low-temperature hydrothermal activity found 3-4 km from the axis [Stakes et al., 2006]. However, even if crustal magma sources for this off-axis volcanism exist over these distances, they are unlikely to account for the much wider region of Moho traveltime anomalies at this segment.

[27] On the basis of these considerations, thicker crust is a more likely explanation for the enhanced Moho traveltimes beneath the axis-centered plateaus found at Endeavour and Cleft segments. Inferred crustal thickness anomalies of $0.5-1 \mathrm{~km}$ (Figures $4 \mathrm{a}$ and $4 \mathrm{c}$ ) are close to those expected for isostatic compensation of the roughly $100-200 \mathrm{~m}$ of excess relief associated with these features relative to the surrounding abyssal hill topography. For isostatically compensated excess topography of $\delta \mathrm{d}=100-200 \mathrm{~m}$, crustal density $\rho=2700 \mathrm{~kg} / \mathrm{m}^{3}$ and mantle density $\rho=3100 \mathrm{~kg} / \mathrm{m}^{3}$, the expected excess crustal thickness is $\delta \mathrm{d} / 0.24=380-770 \mathrm{~m}$ [Turcotte and Schubert, 2002]. 
[28] The presence of thicker crust beneath these axis-centered plateaus at Cleft and Endeavour compared with typical ridge flank values implies a recent increase in crustal production at these segments. As discussed below, we attribute these recent changes to initiation of ridge axis-centered melt anomalies associated with the Cobb hot spot and the Heckle seamount source giving rise to enhanced melt production at Cleft and Endeavour segments respectively.

\subsection{Enhanced Crustal Production Along the Southern JDFR and Possible Association With Cobb Hot Spot}

[29] Assuming a constant spreading rate of $56 \mathrm{~mm} /$ a, a maximum age of $0.57 \mathrm{Ma}$ for onset of enhanced crustal production at Cleft segment is estimated from the $32 \mathrm{~km}$ width of the axiscentered plateau. The uniform width of this plateau to its southernmost extent and the greater Moho traveltimes found on seismic lines to within $15 \mathrm{~km}$ of the Blanco FZ [Canales et al., 2005], indicate a rapid increase in crustal production along the length of the segment at this time. Conjugate outward facing slopes define a plateau of similar width (age) at the adjacent Vance segment to the north (Figure 2b) and a contemporaneous increase in magma supply to Vance segment is implied. Seismic data are available for the Vance segment plateau and indicate excess crustal thickness relative to our average ridge flank values, although the inferred anomaly $(\sim 100 \mathrm{~m})$ is smaller than that at Cleft segment (up to $300 \mathrm{~m}$ ) [Canales et al., 2005]. From their study of magnetic and bathymetric data, Delaney et al. [1981] estimate that Axial segment initiated within the Brunhes anomaly at $\sim 0.5 \mathrm{Ma}$ with a $20 \mathrm{~km}$ westward jump of the axis to override the Cobb hot spot. This timing is close to the estimated age of onset of enhanced crustal production at Cleft and Vance segments and we infer that enhanced melt production beneath these segments initiated rapidly linked to development of this onaxis hot spot.

[30] The morphology of Coaxial segment, located immediately north of Axial, suggests recent onset of magma "oversupply" to this ridge segment as well, linked to proximity to Axial Volcano. This segment is associated with a prominent plateau distinct from surrounding seafloor, that rises 400-600 $\mathrm{m}$ and which tapers in width from $16 \mathrm{~km}$ near Axial to $10 \mathrm{~km}$ at its northern end, $\sim 75 \mathrm{~km}$ north of the summit of Axial (Figure 2b) [Embley et al., 2000]. Elevated plateau shoulders form half pear shapes in plan view, and near the north rift zone of Axial segment have the appearance of a bisected seamount presumably linked to the abundant nearby seamounts and the Axial melt anomaly.

[31] From two-dimensional modeling of an alongaxis bathymetry and gravity profile constructed from archived ship track data, Hooft and Detrick [1995] infer a mantle thermal anomaly of $30-40^{\circ} \mathrm{C}$ and a zone of $1-2 \mathrm{~km}$ thicker crust extending $\sim 100 \mathrm{~km}$ along axis beneath Axial and adjacent Coaxial segment, which they attribute to effects of the Cobb hot spot. Preliminary analysis of gravity data collected simultaneous with our seismic survey support thickened crust within the near axis region at Cleft segment but not Northern Symmetric (Figure 8). Residual gravity anomalies calculated for the flank transects assuming a constant thickness crust indicate lower densities are needed at the axis of Cleft segment relative to the other two segments consistent with thicker crust (or warmer crust and/or mantle) at Cleft (Figure 8a). In comparison, models calculated using crustal thicknesses constrained by the seismic observations explain most of the difference in residual anomalies at the axis of the three segments (Figure 8b). More comprehensive analysis of gravity data collected during our study will be presented elsewhere.

[32] Considered together these bathymetric, gravity, and seismic data reveal the presence of elevated plateau with thickened crust centered on the ridge axis from Cleft to Coaxial that initiated close in time to onset of the on-axis hot spot at Axial Volcano. Bathymetric swells and gravity anomalies indicative of thicker crust are commonly observed where hot spots approach, intersect, and recede from mid-ocean ridges and are attributed to flow of plume mantle toward and along ridges [e.g., Ito and Lin, 1995]. From their analysis of bathymetric and gravity anomalies in the vicinity of several ridge-crossing hot spots Ito and Lin [1995] find that the magnitude and along-axis extent of these anomalies are greatest when the hot spot is centered beneath the axis. Modeling studies of ridgeplume interactions indicate that, under conditions of low viscosities in the shallow mantle and thin plume layers, the topography of the lithosphere at ridges may effectively channel flow of plume mantle leading to "pipe-like" along-axis flow [e.g., Sleep, 1996; Ribe et al., 1995; Georgen and Lin, 2003]. Rapid initiation of enhanced crustal production along the southern JDFR with onset of 

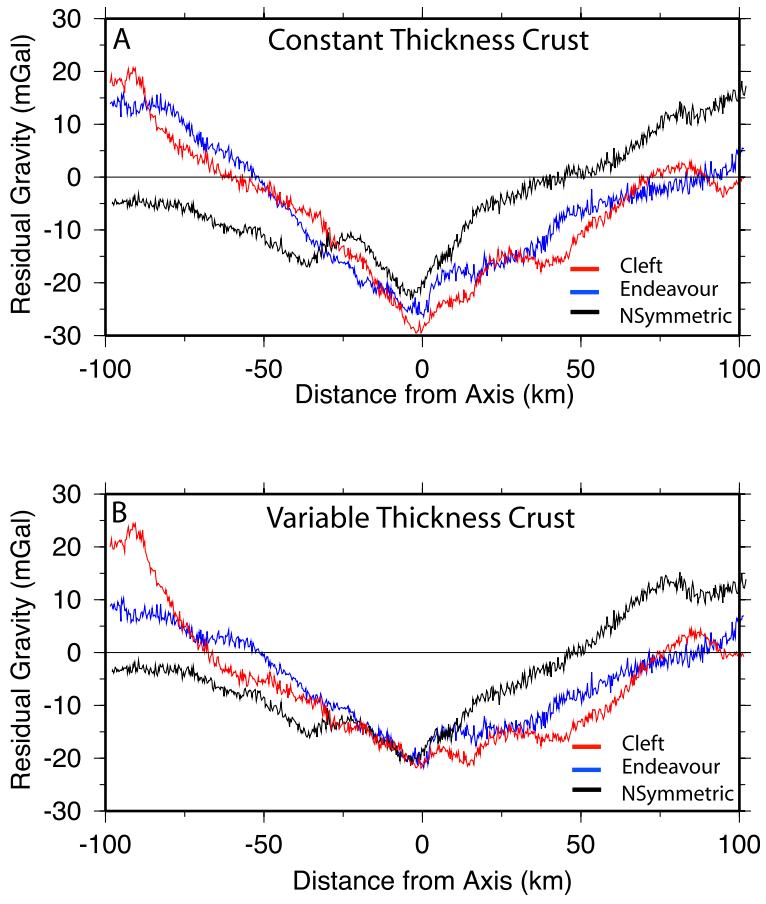

Figure 8. Residual gravity anomalies calculated for Endeavour, Northern Symmetric, and Cleft ridge flank profiles in Figures $3 a-3 d$ (a) assuming a uniform crustal thickness of $6.5 \mathrm{~km}$ and (b) using variable crustal thickness constrained by Moho observations from Figures $4 \mathrm{a}-4 \mathrm{c}$. Residual anomalies correspond to observed gravity minus theoretical gravity obtained for each case with depths to all other crustal layers constrained by the seismic data (seafloor, top of oceanic crust, base of layer 2A). Horizontal axis is distance along profile in kilometers away from ridge axis. For all models, densities within layer $2 \mathrm{~A}$ are determined from 2A velocities of Nedimovic et al. [2005a] using the empirical density-velocity relation of Carlson and Raskin [1984]. Constant densities are assumed for all other crustal layers $\left(1.03 \mathrm{~g} / \mathrm{cm}^{3}\right.$ for water, $1.9 \mathrm{~g} / \mathrm{cm}^{3}$ for sediments, $2.75 \mathrm{~g} / \mathrm{cm}^{3}$ for layer $2 \mathrm{~B} / 3$, and $3.3 \mathrm{~g} / \mathrm{cm}^{3}$ for mantle). No corrections are included for cooling of crust-mantle zone away from the ridge axis. Negative residual anomalies are obtained for the axial region along all profiles, with the largest (most negative) anomalies at Cleft segment. (a) residual anomalies obtained assuming constant $6.5 \mathrm{~km}$ thick crust for all segments are $\sim 10 \mathrm{mGal}$ lower at the axis of Cleft segment compared to Northern Symmetric segment and indicate that significantly lower densities (or thicker crust) are required at Cleft. (b) Using the variable crustal thickness constrained by the seismic observations, differences in residual anomalies at the axis of the three segments are minimal ( $3 \mathrm{mGal}$ lower at Cleft segment).

Axial Volcano implies efficient pipe-like flow linked to the on-axis hot spot, low shallow mantle viscosities, and a thin layer of anomalous mantle.
[33] In contrast to the geophysical observations, geochemical data suggest that Cobb hot spot influence is limited to Axial segment. Unlike most hot spot seamount chains, basalts from the Cobb-Eickelberg chain have essentially normal MORB-like isotopic compositions, with no evidence of isotopic enrichment relative to basalts from the adjacent JDFR. On the basis of the lack of isotopic enrichment, early geochemical studies concluded that the Cobb hot spot was primarily a thermal anomaly rather than a compositionally distinct enriched mantle plume [Desonie and Duncan, 1990; Rhodes et al., 1990]. However, more recent detailed geochemical studies demonstrate that the Cobb hot spot does produce basalts with distinct geochemical characteristics including enrichments in alkalis and highly incompatible elements [Chadwick et al., 2005; Rhodes et al., 1990]. Using these characteristics as chemical tracers of the Cobb source, Chadwick et al. [2005] conclude that Cobb hot spot influence is confined to Axial segment with gradients along the rift zones of Axial Volcano indicative of enhanced fractional crystallization with increasing distance from the volcano summit. Geochemical data from the 1993 eruption at Coaxial segment indicate the magmatic plumbing system beneath Coaxial at present is separate from that of Axial Volcano [Embley et al., 2000]. Similarly, there is no geochemical evidence of hot spot influence on segments to the south of Axial segment [e.g., Rhodes et al., 1990].

[34] Together, these geochemical studies suggest a much narrower extent of Axial hot spot influence along the JDFR than that inferred from the bathymetric and gravity anomalies, and seismically estimated crustal thickness. This decoupling between geochemical and geophysical anomalies along mid-ocean ridges with nearby hot spots is observed elsewhere including the Mid Atlantic Ridge in the vicinity of the Iceland and Azores hot spots [e.g., Ito et al., 2003] and along the Galapagos Spreading Center [Cushman et al., 2004]. For example, whereas geochemical data indicate the mantle source signature of the Azores hot spot extends to the Hayes FZ [Schilling et al., 1983; Debaille et al., 2006], the thermal effect of the hot spot estimated from bathymetric and gravity anomalies extends over $800 \mathrm{~km}$ further south to $\sim 26^{\circ} 30^{\prime} \mathrm{N}$ [Thibaud et al., 1998; Ito et al., 1997]. The origin of these discrepancies between geochemical and geophysical indicators associated with ridge-hot spot interaction are poorly understood. The role of volatiles, in particular water, on melting and chemical extraction are likely to be 
important [Asimow and Langmuir, 2003; Cushman et al., 2004]. Entrained ambient mantle associated with upwelling mantle plumes may also contribute.

\subsection{Enhanced Crustal Production at Endeavour Segment Associated With Heckle Seamount Source}

[35] From Moho traveltime anomalies we estimate that crust beneath the $\sim 40 \mathrm{~km}$ wide plateau at Endeavour segment is $\sim 0.5-1.0 \mathrm{~km}$ thicker than the average thickness beneath the ridge flanks (Figure 4a). The age of crust at the plateau edges, estimated from magnetic anomalies, is $0.71 \mathrm{Ma}$ and we interpret development of this plateau as resulting from the northwesterly migrating JDFR overriding the melt anomaly associated with the Heckle seamount chain just after onset of the Brunhes anomaly (Figure 2a). Prior to the Brunhes, Northern Symmetric segment had propagated steadily north for $\sim 3$ Ma. However, propagation direction reversed during the Brunhes and Endeavour segment rapidly propagated south $\sim 35 \mathrm{~km}$ (Figure 2a). This southward propagation may be directly linked to enhanced ridge axis melt supply and along-axis channeling of the Heckle anomaly following ridge capture. At young crustal ages $(<200,000$ years $)$ there is evidence for a small eastward jump of the Endeavour axis (Figures 2a and 2c) which could reflect readjustment of the plate boundary to remain approximately centered on the Heckle melt anomaly with ongoing northwesterly migration of the JDFR. Magnetic data show that the Brunhes anomaly is not symmetric about the current axis, and is $3 \mathrm{~km}$ wider on the west flank (Figure 2a). The prominent ridge centered $5.5 \mathrm{~km}$ west of the ridge axis has similar morphology and dimensions to the current axis, including a $<1.0 \mathrm{~km}$ wide central rift graben, and is the inferred former ridge location (Figures $2 \mathrm{a}$ and $2 \mathrm{c})$. A conjugate partial ridge is present east of the current axis within the southern part of the segment indicating that the axis jump was confined within the axial rift of this region. Renewed northward propagation of Northern Symmetric segment has occurred in the past 100,000 years [Shoberg et al., 1991], which may reflect a current waning in influence of the Heckle anomaly on melt production at Endeavour segment as this anomaly is transferred to the east flank of the ridge.

[36] Lavas from Endeavour segment are unusual along the JDFR in that they are on average the most enriched in incompatible elements and most diverse in compositional types [Karsten, 1988;
Woodcock et al., 2007]. Recent detailed sampling within the axial graben floor and shoulders of Endeavour segment indicate that the wide variety of MORB chemical types require variations in extents of melting as well as multiple mantle sources [Woodcock et al., 2007]. Karsten [1988] attributed the presence of highly enriched lavas at Endeavour to contribution of the Heckle melting anomaly to spreading ridge melts. However, subsequent geochemical sampling of Heckle and the nearby Heck seamounts to the north indicate these lavas come from a highly depleted mantle source and there is no evidence that the enriched component sampled at the Endeavour axis is linked to Heckle melts [Leybourne and Van Wagoner, 1991, Cousens et al., 1995]. On the basis of these geochemical data the origin of enhanced melting associated with formation of the Heckle seamount chain appears to require a shallow thermal anomaly within a depleted mantle source rather than an enriched compositional heterogeneity [Leybourne and Van Wagoner, 1991]. The Vance seamounts located on the western flank of Vance segment are similar in that they are more depleted than the adjoining ridge axis lavas although enriched MORB compositions are also found [Wendt et al., 2007]. Although the nature of mantle processes that give rise to small off-axis seamount chains including the Heckle (and Vance) are not well understood, the prevailing view is that they are linked to small-scale thermal anomalies and heterogeneities within the shallow mantle [Scheirer and Macdonald, 1995; Wilson, 1992]. Morphologic and seismic observations, along with the recent tectonic history of the region provide strong support for increasing interaction at younger crustal ages between the Heckle melt source and the ridge axis, consistent with migration of the JDFR toward this mantle heterogeneity. Interaction between the melt source for the Vance seamounts and the adjacent ridge axis is evident in the field of small volcanic cones on the west flank of Vance segment and the current offset axial volcanic ridges centered within the current axial rift (Figure 2b) [Canales et al., 2005]. In addition to Axial hot spot, this melt anomaly may also contribute to increased crustal production over the past $0.57 \mathrm{Ma}$ along the southern JDFR.

[37] Comparison of the structural anomalies at Endeavour segment with those at Cleft to Coaxial segments indicates that the geophysical manifestations of ridge-melt anomaly interaction along the JDFR are similar and analogous to those observed at much larger on-axis hot spots. Although the 
scale of impact differs, in each region, an elongate ridge-parallel plateau with thickened crust is found, indicating enhanced ridge-axis melt production and rapid along-axis propagation of the melt anomaly following ridge capture.

\subsection{Absolute Plate Motions and Subaxis Melt Distribution}

[38] Bathymetric studies of fast and intermediate spreading ridges reveal a distinct asymmetry in ridge axis depths near discontinuities linked to the direction of absolute motion of the ridge axis [Carbotte et al., 2004; Supak et al., 2007]. Leading segments (those offset at a discontinuity in the direction of ridge absolute motion) are consistently shallower, with higher inferred magma supply relative to the adjoining trailing segments. These recent studies focus on the local depth asymmetries observed across discontinuities. However, within the framework of the large-scale segmentation of the JDFR, the regional-scale south-to-north gradients observed along the ridge in axis depth and cross-axis dimensions of the axial high are also consistent with this pattern; the shallow, broad Cleft segment is a leading segment whereas the deeper, narrow Endeavour is a trailing segment. Seismic data reveal gradients along the JDFR in subseafloor structure consistent with the bathymetric trends; the crustal magma lens is shallower and more uniform in depth beneath the southern JDFR segments whereas it is deeper on average and present at a wider range of depths at Northern Symmetric and Endeavour (Figure 6). With the exception of Axial Volcano, the leading Cleft segment is associated with the shallowest, and most persistent magma lens along the JDFR. In contrast, a midcrust magma lens is only detected beneath $20 \%$ of the trailing Endeavour segment and is possibly only present because of ridge capture of the Heckle melt anomaly (Table 1 and Figure 6). Our data indicate enhanced crustal production during the Brunhes at both of these segments linked to local melt anomalies. However, proximity to these anomalies alone cannot explain the regional-scale along-axis trends. Seafloor morphological parameters and magma lens properties indicate a warmer axial regime at Cleft than either Vance or Coaxial segments, both of which are located closer to the on-axis hot spot at Axial Volcano. In addition, inferred crustal thicknesses within the inner $30 \mathrm{~km}$ about the axis are higher at Cleft than at Vance segment indicating greater crustal production at this southernmost segment in the recent past.
[39] Carbotte et al. [2004] propose that the influence of absolute motion of the spreading plate boundary on mantle melting may give rise to differences in melt availability to adjacent leading and trailing segments through melt tapping across the bounding discontinuity. This mechanism is expected to be limited to the near-discontinuity region unless significant large-scale along-axis redistribution of mantle melt occurs. Additional factors linked to the absolute motion of the ridge axis may contribute to the larger-scale along-axis variations observed at the JDFR. Davis and Currie [1993] note that the deep rift morphology of the northernmost JDFR could reflect diminished magma supply linked to the northwestward motion of the ridge over the asthenosphere in the wake of the Explorer plate. In this scenario, mantle melt availability at the trailing Endeavour and West Valley segments may be limited by prior upwelling beneath the adjacent leading segment (South Explorer Ridge) as the segmented ridge axis sweeps obliquely over the deeper mantle. An alternate hypothesis proposed by Schouten et al. [1987] is that absolute motion of the plates may give rise to subcrustal along-axis asthenospheric flow at a rate and direction equal to the axis-parallel component of motion of the hot spot frame relative to the ridge axis (Figure 9). Along-axis flow is predicted from this model only if the absolute motion of the ridge axis is oblique to the spreading direction. The absolute motion of the JDFR axis is oriented $38^{\circ}-49^{\circ}$ oblique to spreading direction $\left(110^{\circ}\right)$ and southward directed along-axis flow is predicted (Figure 9a).

[40] From morphologic, gravity, and seismic observations along the southern JDFR we infer influence of the Cobb hot spot on melt supply to the JDFR which reaches over twice as far south of the current hot spot location at Axial Volcano as to the north. The southward propagation of Endeavour segment since ridge capture of the Heckle anomaly, which is evident in magnetic and morphological data, indicates southward directed along-axis channeling of this melt anomaly as well. Preferential along-axis channeling of these melt anomalies to the south could be linked to the northwestward migration of the JDFR, following the model of Schouten et al. [1987] (Figure 9). Perhaps damming of southward directed channeled subaxial flow by the largeoffset Blanco TF [e.g., Georgen and Lin, 2003] plays a role in the excess crustal production at Cleft segment compared with Vance. Beneath most JDFR segments there is a notable asymmetry in AMC depths with shallower magma lens to the 


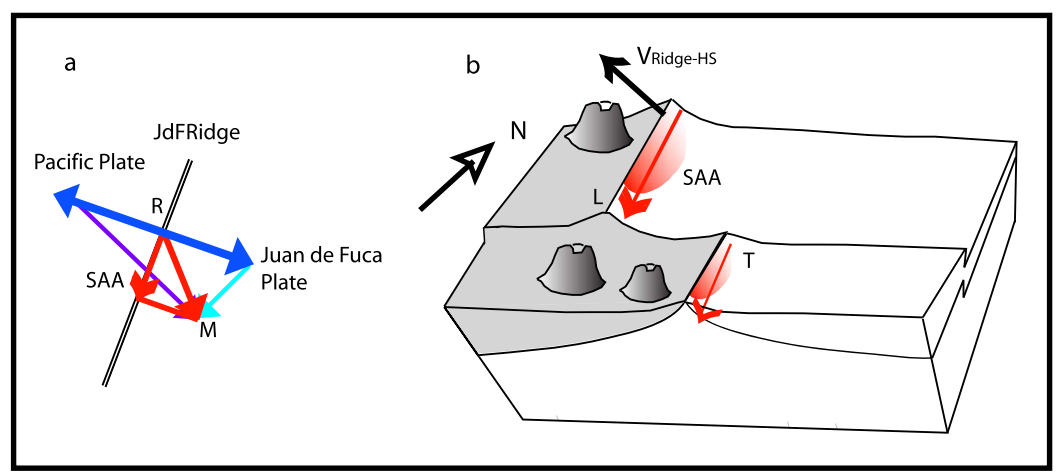

Figure 9. Model for influence of absolute plate motions on ridge-melt anomaly interaction. (a) Predicted direction of subaxial asthenospheric (SAA) flow beneath the JDFR axis following Schouten et al. [1987] arising from absolute motion of the spreading plate boundary relative to the underlying deeper mantle. Relative motion of the Pacific and Juan de Fuca plates is shown in blue, absolute motion of Pacific plate is shown in purple, and Juan de Fuca plate is shown in light blue. Predicted motion of the mantle (M) referenced to the ridge axis at $\mathrm{R}$ is shown in red with axisparallel and -perpendicular components indicated. Velocity vectors are calculated from absolute plate motion model HS3-Nuvella for the JDFR axis at $48^{\circ} \mathrm{N}$ [Gripp and Gordon, 2002]. (b) Schematic illustration showing a segmented MOR approaching and overriding localized melting anomalies in the shallow mantle associated with off-axis seamount chains. Absolute motion of the plate boundary to the northwest gives rise to preferential southward directed along-axis flow (red arrows) of the captured melt anomalies. Figure modified from Carbotte et al. [2004].

south indicating a warmer axial regime (Figure 5). This warmer-to-the-south trend could also reflect southward directed subaxial asthenospheric flow induced by absolute motion of the ridge axis.

\section{Conclusions}

[41] Seismic reflection and bathymetric data from the JDFR reveal a recent history of ridge-hot spot interaction which we associate with the Cobb hot spot and the Heckle melt anomaly. In both cases the physical manifestations of ridge-melt anomaly interaction include elongated axis-parallel plateau elevated a few hundreds of meters above surrounding seafloor and associated with thickened crust consistent with isostatic compensation of the excess topography. Given the available age constraints, onset of enhanced crustal production closely follows onset of the on-axis hot spot indicating rapid along-axis channeling of anomalous mantle. The scale of impact inferred from the structural anomalies differs in the two regions, presumably because of differences in melt anomaly flux. In both areas, the impact of these melt anomalies on the ridge axis regime may be primarily thermal rather than compositional. The alongaxis extent of Cobb hot spot influence estimated from the geophysical anomalies is much wider than that inferred from the geochemical data and anomalous melting of ambient mantle is inferred.
[42] An important conclusion of this study is that the structure and tectonic history of Endeavour segment, including the current distribution of melt beneath the axis and southward propagation during the early Brunhes, are directly linked to presence of the Heckle melt anomaly. There is also evidence for a small recent ridge jump to the east, which may reflect transfer of the Heckle anomaly to the eastern flank of the ridge with ongoing northwesterly migration of the JDFR. A return to northward propagation of Northern Symmetric segment in the past 100,000 years may reflect waning influence of the Heckle anomaly on magma supply at Endeavour segment as the ridge now migrates away from this anomaly.

[43] Seismic and bathymetric data reveal south-tonorth gradients in ridge morphological parameters and melt distribution within the crust, which indicate a general trend of warmer to the south within individual ridge segments and along the JDFR as a whole. These trends cannot simply be attributed to hot spot proximity and may be linked to influence of the absolute motion of the JDFR on mantle melting and melt distribution beneath the ridge axis. Along-axis asthenospheric flow induced by the obliquely migrating JDFR or variations in mantle fertility due to prior partial melting and melt extraction as the ridge continuously migrates to the northwest over the deeper mantle could contribute to the along-axis gradients observed. Regional variations in ridge properties along the 
JDFR relative to the large-scale segmentation and absolute motion of the axis, are consistent with observations elsewhere along the global MOR and support the notion that plate kinematics plays an important role in the magmatic segmentation of ridges.

\section{Acknowledgments}

[44] Thanks to Mike Perfit, Gail Christeson, and Associate Editor Peter Van Keken for their careful reviews which greatly improved the manuscript. This work was supported by U.S. National Science Foundation grants OCE00-02488 to S.M.C., OCE06-48303 to S.M.C. and M.R.N., OCE-0648923 to J.P.C., and OCE00-02600 to G.M.K. and A.J.H. This is LDEO contribution 7152 .

\section{References}

Asimow, P. D., and C. H. Langmuir (2003), The importance of water to oceanic mantle melting regimes, Nature, 421, 815820, doi:10.1038/nature01429.

Barclay, A. H., and W. S. D. Wilcock (2004), Upper crustal seismic velocity structure and microearthquake depths at the Endeavour segment, Juan de Fuca Ridge, Geochem. Geophys. Geosyst., 5, Q01004, doi:10.1029/2003GC000604.

Canales, J. P., R. S. Detrick, S. M. Carbotte, G. M. Kent, J. B. Diebold, A. J. Harding, J. M. Babcock, M. R. Nedimović, and E. Van Ark (2005), Upper crustal structure and axial topography at intermediate spreading ridges: Seismic constraints from the southern Juan de Fuca Ridge, J. Geophys. Res., 110, B12104, doi:10.1029/2005JB003630.

Canales, J. P., S. C. Singh, R. S. Detrick, S. M. Carbotte, A. J. Harding, G. M. Kent, J. B. Diebold, J. Babcock, and M. R. Nedimović (2006), Seismic evidence for variations in axial magma chamber properties along the southern Juan de Fuca Ridge, Earth Planet. Sci. Lett., 246, 353-366, doi:10.1016/ j.epsl.2006.04.032.

Carbotte, S. M., A. Solomon, and G. Ponce-Correa (2000), Evaluation of morphological indicators of magma supply and segmentation from a seismic reflection study of the East Pacific Rise $15^{\circ} 30^{\prime}-17^{\circ} \mathrm{N}$, J. Geophys. Res., 105, $2737-$ 2759, doi:10.1029/1999JB900245.

Carbotte, S. M., C. Small, and K. Donnelly (2004), The influence of ridge migration on the magmatic segmentation of mid-ocean ridges, Nature, 429, 743-746, doi:10.1038/ nature 02652 .

Carbotte, S. M., R. S. Detrick, A. Harding, J. P. Canales, J. Babcock, G. Kent, E. Van Ark, M. Nedimovic, and J. Diebold (2006), Rift topography linked to magmatism at the intermediate spreading Juan de Fuca Ridge, Geology, 34, 209-212, doi:10.1130/G21969.1.

Carlson, R. L., and G. S. Raskin (1984), Density of the ocean crust, Nature, 311, 555-558.

Chadwick, J., M. Perfit, I. Ridley, I. Jonasson, G. Kamenov, W. Chadwick, R. Embley, P. le Roux, and M. Smith (2005), Magmatic effects of the Cobb hot spot on the Juan de Fuca Ridge, J. Geophys. Res., 110, B03101, doi:10.1029/ 2003JB002767.

Christensen, N. I. (1979), Compressional wave velocities in rocks at high temperatures and pressures, critical thermal gradients, and crustal low-velocity zones, J. Geophys. Res., 84, 6849-6857, doi:10.1029/JB084iB12p06849.
Christeson, G. L., G. M. Purdy, and K. M. M. Rohr (1993), Structure of the Northern Symmetrical segment of the Juan de Fuca Ridge, Mar. Geophys. Res., 15, 219-240, doi:10.1007/BF01204234.

Christeson, G. L., K. D. McIntosh, and J. A. Karson (2007), Inconsistent correlation of seismic layer $2 \mathrm{a}$ and lava layer thickness in oceanic crust, Nature, 445, 418-421, doi:10.1038/nature05517.

Cousens, B. L., J. A. Allen, M. I. Leybourne, R. L. Chase, and N. Van Wagoner (1995), Mixing of magmas from enriched and depleted mantle sources in the northeast Pacific: West Valley segment, Juan de Fuca Ridge, Contrib. Mineral. Petrol., 120, 337-357, doi:10.1007/BF00306512.

Cudrak, C. F., and R. M. Clowes (1993), Crustal structure of Endeavour Ridge segment, Juan de Fuca Ridge, from a detailed seismic refraction survey, J. Geophys. Res., 98, 63296349, doi:10.1029/92JB02860

Cushman, B., J. Sinton, G. Ito, and J. Eaby Dixon (2004), Glass compositions, plume-ridge interaction, and hydrous melting along the Galápagos Spreading Center, $90.5^{\circ} \mathrm{W}$ to $98^{\circ} \mathrm{W}$, Geochem. Geophys. Geosyst., 5, Q08E17, doi:10.1029/ 2004GC000709.

Davis, E. E., and R. G. Currie (1993), Geophysical observations of the northern Juan de Fuca Ridge system: Lessons in seafloor spreading, Can. J. Earth Sci., 30, 278-300.

Davis, E. E., and J. L. Karsten (1986), On the cause of the asymmetric distribution of seamounts about the Juan de Fuca Ridge: Ridge-crest migration over a heterogeneous asthenosphere, Earth Planet. Sci. Lett., 79, 385-396, doi:10.1016/ 0012-821X(86)90194-9.

Davis, E. E., et al. (1992), FlankFlux: An experiment to study the nature of hydrothermal circulation in young oceanic crust, Can. J. Earth Sci., 29, 925-952.

Debaille, V., J. Blichert-Toft, A. Agranier, R. Doucelance, P. Schiano, and F. Albarede (2006), Geochemical component relationships in MORB from the Mid-Atlantic Ridge, $22-35^{\circ} \mathrm{N}$, Earth Planet. Sci. Lett., 241, 844-862, doi:10.1016/j.eps1.2005.11.004.

Delaney, J. R., H. P. Johnson, and J. L. Karsten (1981), The Juan De Fuca Ridge-hot spot-propagating rift system: New tectonic, geochemical, and magnetic data, J. Geophys. Res., 86, 11,747-11,750, doi:10.1029/JB086iB12p11747.

Desonie, D. L., and R. A. Duncan (1990), The Cobb-Eickelberg seamount chain: Hotspot volcanism with mid-ocean ridge basalt affinity, J. Geophys. Res., 95, 12,697-12,711, doi:10.1029/JB095iB08p12697.

Dunn, R. A., D. R. Toomey, and S. C. Solomon (2000), Threedimensional seismic structure and physical properties of the crust and shallow mantle beneath the East Pacific Rise at $9^{\circ} 30^{\prime} \mathrm{N}$, J. Geophys. Res., 105, 23,537-23,555, doi:10.1029/2000JB900210.

Embley, R. W., and D. S. Wilson (1992), Morphology of the Blanco Transform Fault zone-NE Pacific: Implications for its tectonic evolution, Mar. Geophys. Res., 14, 25-45, doi:10.1007/BF01674064.

Embley, R. W., K. M. Murphy, and C. G. Fox (1990), High-resolution studies of the summit of Axial Volcano, J. Geophys. Res., 95, 12,785-12,812, doi:10.1029/ JB095iB08p12785.

Embley, R. W., W. W. Chadwick, M. R. Perfit, M. C. Smith, and J. R. Delaney (2000), Recent eruptions on the Coaxial segment of the Juan de Fuca Ridge: Implications for midocean ridge accretion processes, J. Geophys. Res., 105, 16,501-16,525, doi:10.1029/2000JB900030.

Fornari, D. J., R. M. Haymon, M. R. Perfit, T. K. P. Gregg, and M. H. Edwards (1998), Axial summit trough of the East 
Pacific Rice $9^{\circ}-10^{\circ} \mathrm{N}$ : Geological characteristics and evolution of the axial zone on fast spreading mid-ocean ridge, J. Geophys. Res., 103, 9827-9855.

Georgen, J. E., and J. Lin (2003), Plume-transform interactions at ultra-slow spreading ridges: Implications for the Southwest Indian Ridge, Geochem. Geophys. Geosyst., 4(9), 9106, doi:10.1029/2003GC000542.

Gripp, A. E., and R. G. Gordon (2002), Young tracks of hotspots and current plate velocities, Geophys. J. Int., 150, 321-361, doi:10.1046/j.1365-246X.2002.01627.x.

Hammond, S. R. (1997), Offset caldera and crater collapse on Juan de Fuca Ridge-flank volcanoes, Bull. Volcanol., 58, 617-627.

Harding, A. J., G. M. Kent, and J. A. Orcutt (1993), A multichannel seismic investigation of upper crustal structure at $9^{\circ} \mathrm{N}$ on the East Pacific Rise: Implications for crustal accretion, J. Geophys. Res., 98, 13,925-13,944, doi:10.1029/ 93JB00886.

Hooft, E. E. E., and R. S. Detrick (1995), Relationship between axial morphology, crustal thickness, and mantle temperature along the Juan de Fuca and Gorda ridges, J. Geophys. Res., 100, 22,499-22,508, doi:10.1029/ 95JB02502.

Ito, G., and J. Lin (1995), Oceanic spreading center-hotspot interactions: Constraints from along-isochron bathymetric and gravity anomalies, Geology, 23, 657-660, doi:10.1130/ 0091-7613(1995)023<0657:OSCHIC > 2.3.CO;2.

Ito, G., J. Lin, and C. W. Gable (1997), Interaction of mantle plumes and migrating mid-ocean ridge: Implications for the Galápagos plume-ridge system, J. Geophys. Res., 102, 15,403-15,417, doi:10.1029/97JB01049.

Ito, G., J. Lin, and D. Graham (2003), Observational and theoretical studies of the dynamics of mantle plume-mid-ocean ridge interaction, Rev. Geophys., 41(4), 1017, doi:10.1029/ 2002RG000117.

Iturrino, G. J., N. I. Christensen, S. Kirby, and M. H. Salisbury (1991), Seismic velocities and elastic properties of oceanic gabbroic rocks from Hole 735B, Proc. Ocean Drill. Program, Sci. Results, 118, 227-244.

Johnson, H. P., and R. W. Embley (1990), Axial Seamount: An active ridge axis volcano on the central Juan de Fuca Ridge, J. Geophys. Res., 95, 12,689-12,696, doi:10.1029/ JB095iB08p12689.

Karsten, J. L. (1988), Spatial and temporal variations in the petrology, morphology, and tectonics of a migrating spreading center: The Endeavour segment, Juan de Fuca Ridge, Ph.D. thesis, 329 pp., Univ. of Wash., Seattle.

Karsten, J. L., and J. Delaney (1989), Hotspot-ridge crest convergence in the northeast Pacific, J. Geophys. Res., 94, 700712, doi:10.1029/JB094iB01p00700.

Karsten, J. L., S. R. Hammond, E. E. Davis, and R. G. Currie (1986), Detailed geomorphology and neotectonics of the Endeavour segment, Juan de Fuca Ridge: New results from Seabeam swath mapping, Geol. Soc. Am. Bull., 97, 213221, doi:10.1130/0016-7606(1986)97<213:DGANOT $>2.0$. $\mathrm{CO} ; 2$.

Kent, G. M., A. J. Harding, J. A. Orcutt, R. S. Detrick, J. C. Mutter, and P. Buhl (1994), Uniform accretion of oceanic crust south of the Garrett transform at $14^{\circ} 15^{\prime} \mathrm{S}$ on the East Pacific Rise, J. Geophys. Res., 99, 9097-9116, doi:10.1029/ 93JB02872.

Kent, G., A. Harding, J. Babcock, J. Orcutt, R. Detrick, J. P. Canales, E. Van Ark, S. Carbotte, J. Diebold, and M. Nedimovic (2003), A new view of 3-D magma chamber structure beneath Axial Seamount and Coaxial segment: Preliminary results from the 2002 multichannel seismic survey of the Juan de Fuca ridge, Eos Trans. AGU, 84(46), Fall Meet. Suppl., Abstract B12A-0755.

Langmuir, C. H., J. F. Bender, and R. Batiza (1986), Petrological and tectonic segmentation of the East Pacific Rise, $5^{\circ} 30^{\prime}-14^{\circ} 30^{\prime} \mathrm{N}$, Nature, 322, 422-429, doi:10.1038/ $322422 \mathrm{a} 0$.

Leybourne, M. I., and N. A. Van Wagoner (1991), Heck and Heckle seamounts, northeast Pacific Ocean: High extrusion rates of primitive and highly depleted mid-ocean ridge basalt on off-ridge seamounts, J. Geophys. Res., 96, 16,27516,293, doi:10.1029/91JB00595.

Lin, J., and J. Phipps Morgan (1992), The spreading rate dependence of three-dimensional mid-ocean ridge gravity structure, Geophys. Res. Lett., 19, 13-16, doi:10.1029/ 91GL03041.

Lin, J., G. M. Purdy, H. Schouten, J.-C. Sempere, and C. Zervas (1990), Evidence from gravity data for focused magmatic accretion along the Mid-Atlantic Ridge, Nature, 344, 627-632, doi:10.1038/344627a0.

Lonsdale, P. (1989), Segmentation of the Pacific-Nazca Spreading Center, $1^{\circ} \mathrm{N}-20^{\circ} \mathrm{S}, \mathrm{J}$. Geophys. Res., 94, $713-$ 743, doi:10.1029/JB094iB01p00713.

Macdonald, K. C. (1982), Mid-ocean ridges: Fine-scale tectonic, volcanic and hydrothermal processes within the plate boundary zone, Annu. Rev. Earth Planet. Sci., 10, 155-190, doi:10.1146/annurev.ea.10.050182.001103.

Macdonald, K. C., P. J. Fox, L. J. Perram, M. F. Eisen, R. M. Haymon, S. P. Miller, S. M. Carbotte, M.-H. Cormier, and A. N. Shor (1988), A new view of the mid-ocean ridge from the behavior of ridge axis discontinuities, Nature, 335 , 217-225, doi: $10.1038 / 335217 \mathrm{a} 0$.

McClain, K. J., and B. T. R. Lewis (1982), Geophysical evidence for the absence of a crustal magma chamber under the northern Juan de Fuca Ridge: A contrast with ROSE results, J. Geophys. Res., 87, 8477-8489, doi:10.1029/ JB087iB10p08477.

McClymont, A. F., and R. M. Clowes (2005), Anomalous lithospheric structure of northern Juan de Fuca plate-A consequence of oceanic rift propagation?, Tectonophysics, 406, 213-231, doi:10.1016/j.tecto.2005.05.026.

McDonald, M. A., J. A. Hildebrand, and S. C. Webb (1994), Seismic structure and anisotropy of the Juan de Fuca Ridge at $45^{\circ} \mathrm{N}, J$. Geophys. Res., 99, 4857-4874, doi:10.1029/ 93JB02801.

Nedimović, M., S. Carbotte, K. Newman, J. Diebold, J. Babcock, A. Harding, G. Kent, P. Canales, and R. Detrick (2005a), Upper crustal evolution along the Juan de Fuca ridge flanks and its relation to sedimentation and tectonic history, Eos Trans. AGU, 86(52), Fall Meet. Suppl., Abstract T33A-0512.

Nedimović, M. R., S. M. Carbotte, A. J. Harding, R. S. Detrick, J. P. Canales, J. B. Diebold, G. M. Kent, M. Tischer, and J. M. Babcock (2005b), Frozen magma lenses below the oceanic crust, Nature, 436, 1149-1152, doi:10.1038/ nature 03944 .

Rhodes, J. M., C. Morgan, and R. A. Liias (1990), Geochemistry of Axial Seamount lavas: Magmatic relationship between the Cobb hotspot and the Juan de Fuca Ridge, J. Geophys. Res., 95, 12,713-12,734, doi:10.1029/ JB095iB08p12713.

Ribe, N. M., U. R. Christensen, and J. Theißing (1995), The dynamics of ridge-plume interaction, 1: Ridge-centered plumes, Earth Planet. Sci. Lett., 134, 155-168, doi:10.1016/ 0012-821X(95)00116-T. 
Scheirer, D. S., and K. C. Macdonald (1995), Near-axis seamounts on the flanks of the East Pacific Rise, $8^{\circ} \mathrm{N}$ to $17^{\circ} \mathrm{N}$, J. Geophys. Res., 100, 2239-2259, doi:10.1029/94JB02769.

Schilling, J. G., M. Zajac, R. Evans, T. Johnston, W. White, J. D. Devine, and R. Kingsley (1983), Petrologic and geochemical variations along the Mid-Atlantic Ridge from 29 degrees $\mathrm{N}$ to 73 degrees N, Am. J. Sci., 283, 510-586.

Schouten, H., K. D. Klitgord, and J. A. Whitehead (1985), Segmentation of mid-ocean ridges, Nature, 317, 225-229, doi: $10.1038 / 317225 \mathrm{a} 0$.

Schouten, H., H. J. B. Dick, and K. D. Klitgord (1987), Migration of mid-ocean-ridge volcanic segments, Nature, 326, 835-839, doi: $10.1038 / 326835 \mathrm{a} 0$.

Shoberg, T., S. Stein, and J. Karsten (1991), Constraints on rift propagation history at the Cobb Offset, Juan de Fuca Ridge, from numerical modeling of tectonic fabric, Tectonophysics, 197, 295-308, doi:10.1016/0040-1951(91)90047-V.

Singh, S. C., et al. (2006), Seismic reflection images of the Moho underlying melt sills at the East Pacific Rise, Nature, 442, 287-290, doi:10.1038/nature04939.

Sleep, N. H. (1996), Lateral flow of hot plume material ponded at sublithospheric depths, J. Geophys. Res., 101, 28,06528,083, doi:10.1029/96JB02463.

Small, C. (1998), Global systematics of mid-ocean ridge morphology, in Faulting and Magmatism at Mid-Ocean Ridges, Geophys. Monogr. Ser, vol. 106, edited by W. R. Buck et al., pp. 1-26, AGU, Washington, D. C.

Small, C., and L. V. Danyushevsky (2003), Plate-kinematic explanation for mid-oceanic-ridge depth discontinuities, Geology, 31, 399-402, doi:10.1130/0091-7613(2003)031< 0399:PEFMDD $>2.0 . C O ; 2$

Stakes, D. S., M. R. Perfit, M. A. Tivey, D. W. Caress, T. M. Ramirez, and N. Maher (2006), The Cleft revealed: Geologic, magnetic, and morphologic evidence for construction of upper oceanic crust along the southern Juan de Fuca Ridge, Geochem. Geophys. Geosyst., 7, Q04003, doi:10.1029/ 2005GC001038.

Supak, S., S. M. Carbotte, and K. C. Macdonald (2007), Influence of ridge migration and proximity to hot spots on the morphology of slow- and intermediate-spreading centers, Geochem. Geophys. Geosyst., 8, Q01010, doi:10.1029/ 2006GC001387.
Thibaud, R., P. Gente, and M. Maia (1998), A systematic analysis of the Mid-Atlantic Ridge morphology and gravity between $15^{\circ} \mathrm{N}$ and $40^{\circ} \mathrm{N}$ : Constraints of the thermal structure, J. Geophys. Res., 103, 24,223-24,243, doi:10.1029/ 97JB02934.

Tivey, M. A., and H. P. Johnson (1990), The magnetic structure of Axial Seamount, Juan de Fuca Ridge, J. Geophys. Res., 95, 12,735-12,752, doi:10.1029/JB095iB08p12735.

Turcotte, D., and J. Schubert (2002), Geodynamics, 2nd ed., Cambridge Univ. Press, New York.

Van Ark, E. M., R. S. Detrick, J. P. Canales, S. M. Carbotte, A. J. Harding, G. M. Kent, M. R. Nedimovic, W. S. D. Wilcock, J. B. Diebold, and J. M. Babcock (2007), Seismic structure of the Endeavour segment, Juan de Fuca Ridge: Correlations with seismicity and hydrothermal activity, J. Geophys. Res., 112, B02401, doi:10.1029/2005JB004210.

Vera, E. E., and J. B. Diebold (1994), Seismic imaging of oceanic layer $2 \mathrm{~A}$ between $9^{\circ} 30^{\prime} \mathrm{N}$ and $10^{\circ} \mathrm{N}$ on the East Pacific Rise from two-ship wide-aperture profiles, J. Geophys. Res., 99, 3031-3041, doi:10.1029/93JB02107.

Wendt, R. E., E. A. Cornejo, M. R. Perfit, B. L. Cousens, and D. A. Clague (2007), Geochemistry of the Vance Seamount chain: Off-axis seamounts along the southern Juan de Fuca Ridge, Eos Trans. AGU, 88(52), Fall Meet. Suppl., Abstract V21B-0609.

West, M., W. Menke, M. Tolstoy, S. C. Webb, and R. A. Sohn (2001), Magma storage beneath Axial Volcano on the Juan de Fuca mid-ocean ridge, Nature, 413, 833-836, doi: $10.1038 / 35101581$.

Wilson, D. S. (1992), Focused mantle upwelling beneath midocean ridges: Evidence from seamount formation and isostatic compensation of topography, Earth Planet. Sci. Lett., 113, 41-55, doi:10.1016/0012-821X(92)90210-M.

Wilson, D. S. (1993), Confidence intervals for motion and deformation of the Juan de Fuca plate, J. Geophys. Res., 98, 16,053-16,071, doi:10.1029/93JB01227.

Wilson, D. S., R. N. Hey, and C. Nishimura (1984), Propagation as a mechanisms of reorientation of the Juan de Fuca Ridge, J. Geophys. Res., 89, 9215-9225, doi:10.1029/ JB089iB11p09215.

Woodcock, J., J. Gill, F. Ramos, and P. Michael (2007), Frequently shifting magma sources at Endeavour segment, Juan de Fuca Ridge, Eos Trans. AGU, 88(52), Fall Meet. Suppl., Abstract V21B-0602. 